University of Louisville

ThinkIR: The University of Louisville's Institutional Repository

Electronic Theses and Dissertations

$5-2021$

\title{
In a Victorian fog: constructing identities in female gothic novels.
}

Hayley Salo

University of Louisville

Follow this and additional works at: https://ir.library.louisville.edu/etd

Part of the Literature in English, British Isles Commons

\section{Recommended Citation}

Salo, Hayley, "In a Victorian fog: constructing identities in female gothic novels." (2021). Electronic Theses and Dissertations. Paper 3596.

https://doi.org/10.18297/etd/3596

This Master's Thesis is brought to you for free and open access by ThinkIR: The University of Louisville's Institutional Repository. It has been accepted for inclusion in Electronic Theses and Dissertations by an authorized administrator of ThinkIR: The University of Louisville's Institutional Repository. This title appears here courtesy of the author, who has retained all other copyrights. For more information, please contact thinkir@louisville.edu. 


\title{
IN A VICTORIAN FOG: CONSTRUCTING IDENTITIES IN FEMALE GOTHIC NOVELS
}

\author{
By \\ Hayley Salo \\ B.A., Simon Fraser University, 2014 \\ M.A., University of Louisville, 2021
}

\author{
A Thesis \\ Submitted to the Faculty of the \\ College of Arts and Sciences \\ in Partial Fulfillment of the Requirements \\ for the Degree of
}

Master of Arts in English

Department of English

University of Louisville

Louisville, Kentucky

May 2021 
Copyright 2021 by Hayley Salo

All rights reserved 



\title{
IN A VICTORIAN FOG: CONSTRUCTING IDENTITIES IN FEMALE GOTHIC NOVELS
}

\author{
By \\ Hayley Salo \\ B.A., Simon Fraser University, 2014 \\ M.A., University of Louisville, 2021
}

A Thesis Approved on

April 6, 2021

by the following Thesis Committee:

Deborah Lutz, Thesis Director

Frank Kelderman, Second Committee Member

Ann Hall, Third Committee Member 


\title{
DEDICATION
}

This thesis is dedicated to my parents

\author{
Russell Salo \\ and \\ Julie Salo
}

who have given me continual support. 


\section{ACKNOWLEDGEMENTS}

I would like to thank my advisor, Dr. Deborah Lutz, for her expertise and support. I would also like to thank my committee members, Dr. Frank Kelderman and Dr. Ann Hall, for their enthusiasm and guidance. Many thanks to the University Writing Center staff and faculty and my good friends in the 2019-2021 English MA cohort, who helped me have a strong start and end to the program. My family has my sincere gratitude: Rob, Shyla, and Marc for listening to my work and woes and for encouraging me; Russ and Julie for teaching me to pursue my goals and for sending bits of home to Kentucky; Leona and ever-remembered John for reminding me of my passion for literature; and Ron, Phyllis, Don, and Mary-Ann for their encouragement. Lastly, many thanks to my pandemic Quaranteam—Tina, Kristofer, Emily, and Dan—for the coordinated supply runs and endless laughs. 


\section{ABSTRACT \\ IN A VICTORIAN FOG: CONSTRUCTING IDENTITIES IN FEMALE GOTHIC NOVELS \\ Hayley Salo}

April 6, 2021

Drawing on feminist criticism and postcolonial theory, this study analyzes conversations about female identity within and around Victorian female gothic novels and how they contribute to the genre's appeal to modern readers. In particular, it is a case study of how the discourse develops through Mary Shelley's Frankenstein (1818), Emily Brontë's Wuthering Heights (1847), and Charlotte Brontë's Jane Eyre (1847). Each novel presents the challenges women face when their sense of self is based on the expectations of others, and Wuthering Heights and Jane Eyre further explore the potential for women to create their own, unique identity while still remaining within an established, patriarchal society. Although none of the novels provide a perfect solution to the problems they identify, they facilitate conversations between writers and readers across generations, thus supporting continued personal development and social change. 


\section{TABLE OF CONTENTS}

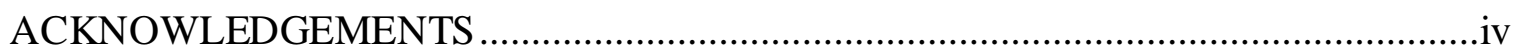

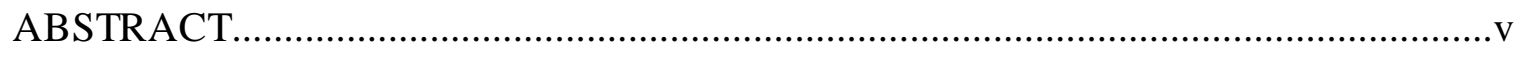

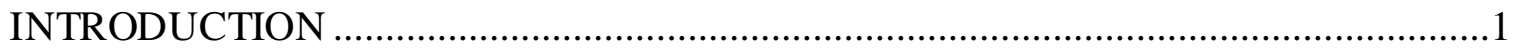

CHAPTER 1 FRANKENSTEIN ........................................................................... 12

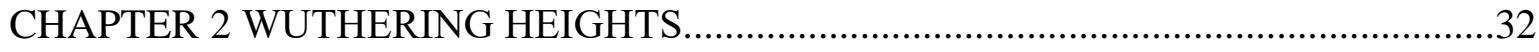

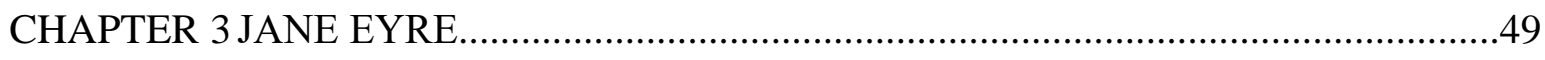

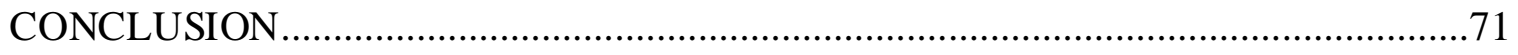

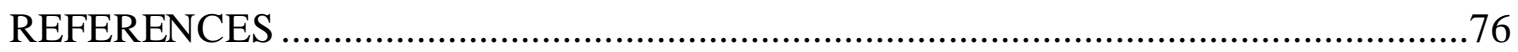

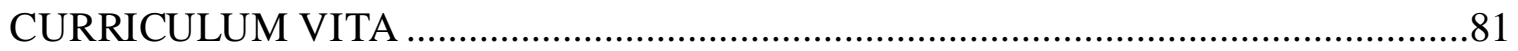




\section{INTRODUCTION}

In 1818, the cries of Frankenstein's creature echoed off the pages: "Cursed creator! Why did I live?” (Shelley 103). His life is scaffolded by the people around him as they physically and mentally create him. Victorian women faced the same challenge as they were urged to follow patriarchal norms for dress, intellect, and station. Failure to meet expectations could lead to social expulsion, yet Frankenstein identifies a potentially greater risk in meeting them. Through the creature, Shelley begins an exploration of women's identities that is woven into the fabric of gothic novels written by women. Following the trends of character development in female gothic novels, the genre emerges as a public_-if coded-discourse on women's identities. The scope of this discourse is visible through Mary Wollstonecraft Shelley's Frankenstein (1818), Emily Brontë's Wuthering Heights (1847), and Charlotte Brontë's Jane Eyre (1847). Together, they explore how accepting patriarchal influences creates risks for everyone involved: female and feminized characters lose their sense of self, and with it, the potential for a fulfilling life; the influential characters — often but not always male-face personal and financial ruin. Everyone is threatened by death. Through these negatives, women's independent identities become the foundation for a positive, stable future.

These novels utilize three stages of selfhood: "identity formation," "constructed identity," and "self-affirmation." The identity formation stage occurs when a female character (child or adult) is learning (or relearning) how their desires and values relate to the people and world around them. During this time, they are particularly open to other 
people's attempts to turn them into a specific kind of person. For instance, the creature, Catherine Earnshaw, Cathy Linton, and Jane Eyre all feel pressure to conform to the standards of the domestic woman, and each accepts or rejects those traits in turn. If the traits are accepted, they contribute to a constructed identity, one where the woman's true self is obscured by her new, outward self. Even when not immediately problematic, constructed identities always become a risk, such as when the creature learns to hate himself, the De Laceys, and humanity when they reject him. While not the goal of each novel — and notably absent form the creature's story — self-affirmation is the given alternative to a constructed identity. In these novels, women have the potential to affirm their unique sense of self when they recognize how they are being influenced and decide, on their own, how to respond. Jane accomplishes this when she breaks free from St. John's persuasion, refusing to become his wife because it does not match her understanding of who she is. However, self-affirmation is not always clear-cut; readers and scholars alike disagree on how Wuthering Heights and Jane Eyre end and what that means for Cathy and Jane's independence. In these instances, even though some elements (and thus risks) of the constructed identities return, the female characters do not lose themselves; they maintain physical and mental agency over themselves, allowing them to avoid the hardships of their past and choose their own sacrifices.

Beyond the basic prominence of female writers and characters, the female gothic genre is adept at addressing these gender identity concerns because it excels at testing and blurring boundaries. Jack Halberstam describes gothic novels as a genre where "readers and writers collaborate in the production of the features of monstrosity," (12) and Kay Mussell views the female gothic as giving women fantasies of "competence" and 
"significance" in their daily lives (61). The gaps between writer, reader, and text are bridged through the inclusion of fantasy and reality. Writers use monsters to symbolize internal struggles and mundane activities to ground the stories in relatable scenarios. The combination allows writers to vocalize otherwise unmentionable challenges, and readers can work through identity questions in a fictional (and thus safe) story that is still easily mapped onto their own lives.

The unmentionable can also be coded into narratives by further utilizing the gaps within the text itself. Feminist criticism in particular has demonstrated the importance of these absences. Elaine Showalter explains that "In the purest feminist literary criticism we are similarly presented with a radical alteration of vision, a demand that we see meaning in what has previously been empty space. The orthodox plot recedes, and another plot, hitherto submerged in the anonymity of the background, stands out in bold relief like a thumbprint" (435). Analyzing absences is no longer as "radical" as Showalter suggests, but respecting the empty spaces remains critical. Most female Victorian writers felt confined in some way and needed a subtle method for sharing ideas, which Patricia Spacks calls the "subterranean challenges" to patriarchy. These challenges are embedded throughout female gothic novels, especially those that end in marriage (317-8). The absences and coded language allowed novelists to publish social critiques with some literary protection or anonymity. Absences also go beyond mere critique, as Sandra Gilbert and Susan Gubar argue that the absent "plot" is "the woman's quest for selfdefinition" (76). Shifting the focus from challenges to patriarchy to personal development emphasizes that the novels are for and about women just as much (if not more) than they are for a more general mass-market. In order to understand dialogue between writers, 
characters, and readers of female gothic novels, then, what is missing is just as important as what is more clearly visible.

Despite the authorial agency that this presence of absence approach grants, scholarship consistently characterizes the female gothic as ineffective at critiquing gender norms. Spacks's final point criticizes the novels and novelists: they "raise questions about women's lot which they do not answer. Do not because, clearly, they can not" (317). At best, the novels fail to clarify what social position women should have, and at worst, they undermine their messages about female independence. The early chapters question gender norms, but the endings encourage women to return to the society they thought they were escaping. Gilbert and Gubar identify a similar pattern where novelists demonstrate "the female impulse to struggle free from social and literary confinement through strategic redefinitions of self, art, and society" (xviii). While Gilbert and Gubar refrain from evaluating the effectiveness of that struggle, the emphasis remains on the confined woman. The impulse is persistent because the confinement is persistent as well; despite their efforts, the writers do not achieve the redefinitions they sought. Women thus become a by-product of confinement, and their narrow existence can only be understood through a patriarchal lens. This view remains common in Victorian scholarship across the decades, including Diane Long Hoeveler's argument that the novels “were thinly disguised efforts at propagandizing a new form of conduct for women" (xv). The conduct gives heroines a false sense of power that turns the female gothic into a genre of "illusory, often self-destructive" escapism (xvi). There are elements of feminine strength in Hoeveler's analysis because women have power over their texts and behaviour, but it resigns women to the passive social role that is lamented by earlier scholars. 
Recent scholarship begins to break down these restrictions. It is not enough for a feminist critic to simply see the challenges female writers portray. Instead, as Carolyn Heilbrun and Catherine Stimpson assert, "an authentic feminist critic would . . . also act to end the deplorable patterns s/he had grappled" with (67). One such pattern is the overreliance on labels. Donna Heiland notes that "the uncanny confronts the subject with something long repressed or forgotten ... the person is literally or figuratively 'haunted' by this reminder of a past that she cannot identify and cannot escape" (6). Likewise, female writers are "haunted" by the "madwoman" and "angel" labels because they cannot be anything else. To break this pattern, it is critical to find the connective path between madwomen and angels and bring the woman as a person into view. Talia Schaffer's argument for familiar marriages in Victorian novels deemphasizes the madwoman/angel binary in favour of a broader discussion of social structures. She describes novels as relationship-focused texts wherein "marriage is a symbolic resolution to a cultural problem" of shifting relationship and social values (4). Novels were a safe space to explore and support a non-romantic, but non-confining, form of marriage. However, this approach still subordinates women's independence by making marriage and family the main point. This project's approach presents the novel as a vehicle for self-affirmation first and marriage second.

Female gothic novels become a vehicle for self-affirmation first and marriage second once additional perspectives on social systems and healing are brought in. Sharon Marcus reimagines relationships between Victorian women by breaking down these systems: "I use 'the play of the system' to conceptualize the yield built into systems. Play signifies the elasticity of systems, their ability to be stretched without permanent 
alteration to their size or shape" (26). The principle of an elastic system applies to identities as well. Mary Shelley's, Emily Brontë's, and Charlotte Brontë's novels contain attempted rebellions, but they are ultimately abandoned, leading scholars (like Spacks) to question the success of each novel's social critique. However, if the characters (and novelists) are working within an elastic system, then they are free to explore multiple routes. A social critique can be effective precisely because it does something new within existing norms, and it avoids the potential long-term consequences associated with changing that system. The narrative structures of Frankenstein, Wuthering Heights, and Jane Eyre all highlight that women do not attempt to dismantle patriarchy or submit to it; rather, they bend social norms to support personal identities. These systems remain relevant even as modern readers return to these works. Where it might seem like women finally broke the Victorian elastic system by advancing women's rights, it may be more accurate to say that one was set aside for another. As laws continue to change and rights expand, new boundaries are put into place. Despite these changes, women continue to empathize with the core elements of female gothic novels even if they also critique some depictions of female characters. Part of the draw of female gothic novels is that the basics of female identity formation remain consistent even as social parameters change.

The way pain and healing are discussed impacts female characters just as much as other characters and their own writers; in particular, looking for full recoveries neutralizes more complex processes. Speaking of Indigenous people's experiences, Sarah Ahmed explains that when "pain ... cannot be shared through empathy," it becomes "a call for action, and a demand for collective politics, as a politics based not on the possibility that we might be reconciled, but on learning to live with the impossibility of 
reconciliation, or learning that we live with and beside each other, and yet we are not as one" (21). Reconciliation too frequently results in assimilation, meaning that Indigenous people do not achieve the freedom and equality they should have. Consequently, they must find another way of healing and identity-making that is built on the acceptance that neither reconciliation nor radical social change is feasible: "The scars on your skin both attach you to a past of loss and a future of survival. This is not healing. But you've moved on" (38). The intent is not to equate the challenges of white Victorian women with those of Indigenous people; Shelley and the Brontës certainly did maintain many of the freedoms taken away from Indigenous people, and their race and citizenship makes them complicit in England's colonial actions. Instead, the intent is to acknowled ge that people who have been hurt cannot always go back to what used to be, if indeed there is a "golden age" to consider returning to at all. Shelly and the Brontës were never going to burn down the metaphorical manor of patriarchy or be contented angels. This is not a fault. Instead of passivity or rebellion, they chose to carve out a position that allowed identity-building and social choices.

Frankenstein, Wuthering Heights, and Jane Eyre are not the only female gothic novels - or novels more generally — that could be used to chart these discussions about female identity. However, they are a logical set because they capture the then-growing possibilities for women in and through print. They represent a beginning, middle, and end to the Victorian conversation of women's identity formation. These are not a literal beginning and end, of course, as women talked about themselves long before and have continued to do so long after. Rather, this sequence of novels demonstrates the way women publicly discussed their ideas in stages, just as their sense of self develops in 
stages. Therefore, it is unreasonable to ask writers and the female gothic in general to answer gender questions in the way some scholars have suggested; there is no "answer" to give. Women learn from women, so the novels are a dialogue between writers-who build on each other's work - that also draws readers into the exchange and application of ideas. Thus, rather than being isolated lessons or a manifesto for women's rights, the novels are a way for women to move forward without radical social change. Frankenstein feminises the monster to demonstrates the need for this approach; Wuthering Heights juxtaposes a Catherine with a clear identity and one without; and Jane Eyre follows Jane's entire identity journey. Tracing the characters' destructive and stable identities in each work proves that the novels encourage female readers to put themselves first, which includes an awareness of and capitalization on familial and social influences.

Frankenstein is an apt starting point because it emphasizes that constructed identities lead to misery and death; it does not offer alternatives. While Frankenstein's narration is full of content and character development, it is startlingly empty of consistent female narration and presence. Victor introduces the memory of his dead mother and childhood with Elizabeth, but for most of the novel, Elizabeth is left behind, heard through letters, or dead. Justine is fondly remembered but emphasized for her unjust death. The creature's bride is also on Victor's mind, yet she never actually lives. Even Agatha and Safie are effectively absent; the monster never talks to them, and they vanish before Felix does. These absent women drive the novel's events. If they never existed, then their absences could not be keenly felt, and Victor's anguish and the monster's hope/revenge would not have manifested. The feminine character with the most presence is the monster: he embodies feminine domestic and social roles, thus paralleling the 
gothic "madwoman" and highlighting the dangers of a fragmented identity. Like many Bildungsroman, his story begins when he is a helpless child, orphaned after Victor flees. When he spies on the De Lacey family, he is a "blank slate" that absorbs the daughter's lessons (Heiland 103-4). Because of this, he is as much the De Lacey daughter as Agatha is. With his early life being decidedly feminine, he parallels two key women in Wuthering Heights and Jane Eyre: like Catherine, he handles his relationship trouble with rage and otherworldly powers (strength and resilience for the monster and hauntings for Catherine). Like Bertha, he threatens Victor's marriage and, by his monstrous potential, his own. His identity is not so much his own as another Frankenstein creation based on the people he meets, and his story ends with no successful marriages or stable lives. His legacy is not a recommendation for how to better oneself or society but a cautionary tale of the dangers and unhappiness tied to women who fail to find their own identities.

Wuthering Heights, as the intermediate text, reiterates Frankenstein's warning and briefly sketches a positive alternative by adding a successful, if troubled, identitybased marriage. The story is told through Mr. Lockwood's experiences, Nelly's memories, Catherine's diary, and retold letters. Because this structure blurs the line between past and present, the novel can juxtapose Catherine's and her daughter's relationships, identities, and future prospects. Like the creature, Catherine lacks an independent identity, mirroring Heathcliff's rebelliousness and believing that they have the same soul (59); since she cannot separate herself from him, she has no opportunity for self-discovery. She appears to develop a sense of self when she marries Edgar Linton, but many of her core traits are still moderated by his desire for a quiet, contented wife. When Heathcliff returns, she faces the competing identities of Catherine Heathcliff and 
Catherine Linton, leaving Catherine Earnshaw-whoever she was meant to be-mentally and physically breaking down, an event that was also foreshadowed by her rewriting her name in the wood at Wuthering Heights (13). Heathcliff and Edgar become a re-imagined Victor, constantly recreating Catherine. The parallel leaves them in a moral grey-area that highlights the dangers of relying on a "monstrous" person for one's own identity. Catherine suffers an early death, Edgar soon follows, and Heathcliff endures a Victoresque torment, harassed by the ghost (or monster) that watches him. Even in death, Catherine is defined by Wuthering Heights.

Cathy (Catherine's daughter) initially takes her mother's path towards a constructed identity. She falls for Linton Heathcliff (and Heathcliff's revenge plot) and becomes the rebellious heroine in distress. However, her overtly problematic marriage allows her to learn what her mother did not: both rebellious and submissive identities lead to misery. Once Linton is gone, she can push against her past experiences and present expectations. Gradually, her rebellion against Heathcliff becomes an assertive relationship with Hareton. Although her education puts her in a position of power, she has no reason to break him. Instead, she encourages him to become who he wants to be, not who Heathcliff made him be. Unlike her mother's relationships, Catherine's marriage to Hareton has promise because both characters have changed. Their new identities allow them to step away from the traumas of Wuthering Heights and into a life at Thrushcross Grange - a stable version of what her mother wanted yet could not achieve.

Jane Eyre, as the culminating text, de-emphasizes the "warning" elements in favour of a positive path: a woman who recognizes, rejects, and accepts influences as needed has the strongest potential for personal stability and happiness. Jane's 
Bildungsroman is a comprehensive exploration of feminine identity. As a child, she understands herself through her aunt and cousin's perceptions of her, at times believing and at other times rejecting their assertions. Transitioning to life at Lowood, a boarding school where she is first a student and later a teacher, she adopts positive traits from her friend Helen Burns and teacher Miss Temple; when both are gone, they take their influence with them. Jane, too, must leave because she cannot be the same person or teacher without them. Similar cycles of making and unmaking herself occur as she falls in love with Rochester, especially when she leaves after learning he is already married, and when she considers a life with her cousins Mary and Diana Rivers or a marriage with her other cousin, St. John Rivers. At each major junction in her life, Jane must face who she wants to be and who she is becoming; her final choice to return to Rochester is not without its sacrifices, but it remains her choice, and she remains who she wanted to be.

These texts draw on the norms of their day, straying far enough to excite change yet remaining close enough to be published, circulated, and discussed, and their arc of gender formation remains pertinent today. Despite living in a very different world, modern women continue to see themselves represented in female gothic novels. The things the characters worked to change have indeed changed, yet the connections felt between generations of women have not. This is because the fundamental aspects of selfhood remain unchanged. Women still need to decide who they want to be and how they will get there, including whether or not they will accept, reject, or adapt the traits others have impressed upon them. Naturally, this is not a female-exclusive experience; it is a human one. And, as people, Mary Shelley, Emily Brontë, and Charlotte Brontë use their characters to make patterns of experiences visible across generations. 


\section{CHAPTER 1: FRANKENSTEIN}

Mary Wollstonecraft Shelley's Frankenstein (1818) plays a foundational role in exploring female identity; it shows that a conversation must occur about it and adds a singular warning to begin it. Through the lives of Victor and the creature, Frankenstein exposes the risks of creating people, but not just in the bodily sense. It delves into the creation of people's sense of self. The creature is the most direct example of a "constructed" person because Victor physically builds him from the remains of other people; from the day he was "born," the creature cannot be himself because he is already a combination of other people's past lives, even if he has no memory of them. The trouble here is equally direct: his resemblance to other humans and inability to look like a single, "normal" human leads others to classify him as a monster. Beyond physicality, he also embodies constructed identities in that he understands himself to be whoever other people show or tell him to be. The De Lacey family has a profound impact on his sense of self because through Agatha and Safie, he forms feminine domestic and intellectual traits. Even then, his situation is precarious because the De Laceys cannot reconcile his physical appearance with his personality, and as they expel him, his sense of self is likewise expelled, restarting his desire for revenge against his creator. At its core, then, Frankenstein offers a social critique of how women are pressured or guided into embodying patriarchal norms. In doing so, it sparks a conversation about why these kinds of social identities are dangerous to women and those around them, though it stops short of offering an alternative. 
As both a story and text, Frankenstein complicates the process of supporting and accepting social norms. Eleanor Salotto describes the 1831 introduction as a text that "resuscitates the dead or body of the traditional narrative of woman, and in its place creates a feminine voice or body that speaks in many different voices, thereby upsetting the notion of a single feminine identity" (191). The creature is equally "upset" in this way as the traits he develops through the De Laceys are also rejected by them, and he and Victor see starkly different potentials for his bride. Judith Butler's discussion of motherchild relationships operates in a similar way: "Shelley's novel implies that replications never turn out quite as we might expect, that there is something monstrous at the core of replication, and that the desire for the perfect copy of a perfected image is not only monstrous, but breeds forms of monstrosity that expose both the impossibility and the cruelty of such a demand" (Butler 43). Creating a woman, then-whether with good or ill intent — is bound to harm her. Salotto's and Butler's analyses also reinforce Berthold Schoene-Harwood assertion "That there are absolutely no limits whatsoever to Frankenstein's significatory spectrum" (7-8). Just as there are multitudes of voices within Frankenstein, those voices can become anything the reader need sthem to be. However, knowing that replication is does not work, virtually any reading that brings aspects of its reader's ideas, experiences, and biases will also contribute to the "monstrosity" of the novel. This flexibility is, perhaps, part of why reviewers found fault with it (its moral was too cleverly hidden) and why it continues to garner attention (the characters' faults are a custom reflection of each reader's fears).

The malleability of characters' voices and reader interpretation strengthens Frankenstein's placement as the foundation for public discourse even as it foreshadows 
its own risks. If one way to read Frankenstein is as a fragmented text that argues against unification and exact copies, it is somewhat problematic that, as a novel, it is able to influence readers' points of view. For female readers specifically, taking its advice to create their own identities is a kind of replication. However, as there are no characters who model who they should be-instead only models of why one should not become someone else-it escapes some of the risks of its own construction. Overwhelmingly, the characters' identities are reflections of what they should be: the moral man, the loyal friend, the good wife. Because they are based on expectations, not core personal values, they rely on external support. When that support is lost, whether through the rebuke of their social equals or the pangs of revenge, each character's grasp on their sense of self weakens, and they are catapulted towards death, taking their loved ones with them. The novel's consistent, precise detailing of its characters' constructed identities — and their own attempts to construct ideal companions - exposes the dangers of such an existence and brings it to life for female readers.

Frankenstein's public reception and publication history demonstrates that any conversation about female identity needed to be coded into a narrative with a more obvious moral. The first edition was published in 1818, and as the chronological and ideological starting point, it will serve as the foundation for this analysis. Many of the original reviews suggest that the points Frankenstein raises about women's identities are critical yet touchy subjects in the public sphere. People are willing to discuss them, but only through the novel (and its perceived flaws) as a kind of proxy. In 1831 (after the death of her husband, Percy), Shelley published a heavily revised version. Like the “censored” version of Oscar Wilde's The Picture of Dorian Gray (1891), Frankenstein 
grew when revised: the text contains substantial additions that amplify its moralizing moments even though, in her new introduction, Shelley calls the revisions "principally those of style" (Shelley 191). To the Victorian public, these revisions may have been agreeable, but they also better hid the novel's discussion of female identity-a boon, perhaps, for those who wished to continue circulating it. Sorting through contemporary reviews of the 1818 version demonstrates that many of the complaints against it were addressed in the 1831 version, making it a kind of censored text that prioritizes patriarchal morals over identity formation. For this reason, this chapter focuses on the 1818 text, its reception, and its original warning.

The basis for coding conversations about women—rather than outright censoring them—-begins with Percy Bysshe Shelley's preface. He writes the preface on Shelly's behalf, turning it into a tool for further coding not only Frankenstein's ideas but also her own authority as a female writer:

I am by no means indifferent to the manner in which whatever moral tend encies exist in the sentiments or characters it contains shall affect the reader; yet my chief concern in this respect has been limited to the avoiding of the enervating effects of the novels of the present day, and to the exhibition of the amiableness of domestic affection, and the excellence of universal virtue. (4)

While conscious of the moral potential of Frankenstein, Percy positions it as a different kind of text. Foremost among the novel's concerns is countering other contemporary novels, instilling life in its readers rather than lethargy. Readers who are energized by Frankenstein are more likely to engage with it and to have the capacity to work through its outer meaning and into its feminized core. "The amiableness of domestic affection, 
and the excellence of universal virtue" are subord inate to this point, suggesting that they, too, have alternate meanings: domesticity becomes an approachable (and thus debatable) topic and virtue is extended to all living, thinking beings. Percy goes on to distance Frankenstein from its writer, noting that "The opinions which naturally spring from the character and situation of the hero are by no means to be conceived as existing always in my own conviction; nor is any inference justly to be drawn from the following pages as prejudicing any philosophical doctrine of whatever kind" (4). This step contextualizes domesticity and virtue as expansive, fluid topics, not ones that a single writer or novel can define. If Shelley has not settled on a single meaning for her own text, then it invites conversation even amongst its harshest critics.

The preface evidently had the intended effect within female literary circles. An anonymous reviewer in the women's magazine Belle Assemblée calls Frankenstein a "bold fiction." The fact that this boldness appeared in print is only somewhat permissible, as "did not the author, in a short preface, make a kind of apology, we should almost pronounce it to be impious" (139). Through the preface, Percy succeeded in surrounding Frankenstein in an air of social acceptability that prevented its immediate dismissal even as it continued to be threatened by other judgements. The reviewer goes on to say,

We hope, however the writer had the moral in view which we are desirous of drawing from it, the presumptive works of man must be frightful, vile, and horrible; ending only in discomfort and misery to himself.

But will all our readers understand this? Should not an author, who has a moral end in view, point out rather that application which may be more generally understood? (139-40) 
The core point this reviewer takes issue with is not what the content is but what it is used for. Their main concern is that the amoral (or monstrous) content of Frankenstein is undeniably provided with a moral point in mind. Even though Percy takes care to put other motivations above moralizing the story, he still demonstrates that Shelley is not oblivious to (or in support of) the corruptive potential of her work, which would have been a larger point of contention. Interestingly, while the obscure moral is a flaw to this reviewer, it serves Frankenstein well by creating more opportunities to develop the female identity conversations nestled below the more obvious moral hints. The 1831 text is significantly more direct with its moralizing, making it more difficult - though not impossible — to locate and continue those conversations.

Once known, Shelley’s gender brought Frankenstein under additional scrutiny, yet that did not negate her ability to reach female readers. One anonymous reviewer for Blackwood's Edinburgh Magazine wrote, "For a man it was excellent; but for a woman it is wonderful" (284). Their praise for her work poorly hides their dismissive attitude towards women more generally. Viewing the novel as a masculine text by a masculine hand implicitly takes control away from Shelley and other women; they are not viewed as capable of writing about the identity matters closest to them, which further pushes them into a constructed, patriarchal box. Indeed, another anonymous reviewer in The British Critic provided an aggressive critique of Shelley, stating, "The writer is, we understand, a female; but if our authoress can forget the gentleness of her sex, it is no reason why we should; and we shall therefore dismiss the novel without further comment" (438). "Forget" here further strips Shelley of agency over her own work. There is no room in this review for the possibility that Shelley was aware of what she was writing and what it 
meant. Consequently, the reviewers appear justified in acting on her behalf to bury it, as if Shelley needed a man's help to overcome a fit of hysteria. And yet, the novel was written by a woman and, even within the text itself, for a woman: in the fictionalized world, Victor and the creature's accounts only survive because Walter wrote them down for his sister, Mrs. Saville. Walter's otherwise personal relationship with Victor becomes part of the familiar domestic — and potentially public — sphere because he saw the value in passing it on to his sister, who can then pass it on to other women. The real-world actions of reviewers in Belle Assemblée and British Critic did not threaten this circulation even as they marginalized the novel for its elements of horror on the grounds that they did not match their social, gendered expectations for writer and text.

But before Frankenstein ever had a preface or reviewers, Shelley utilized familiar female gothic techniques to craft her terrifying dream into a real "ghost story" (Shelley 190)—a sequence of real events dripping with gothic horror trimmings. Despite Shelley's intention, Marshall Brown points out that Frankenstein is nothing of the sort: "Frankenstein is supernatural to the extent that it takes the form of a charmed world" (151). With the supernatural removed —or relegated to the unusual—other gothic elements come to the forefront. Frankenstein's layered narration of letters, conversations, and dreams are a staple of gothic novels, and they are instrumental in setting up and maintaining a lack of control. This lack of control leads to the characters-most notably the creature and his bride — becoming beings they do not (or cannot) recognize. Consequently, the novel frames constructed identities as undesirable and potentially fatal. Criscillia Benford breaks down Frankenstein's structure through its inassimilable content, which "is an element (e.g., a character, event, narrative technique) that calls 
attention to a text's constructedness by simultaneously activating two or more competing, yet equally plausible, sense-making frames" (325). The varied styles of written and spoken narration give the novel an artificial feel. By shifting between people and places, the novel stops being a single sequence of events and becomes a simultaneously guided and free-roam journey through multiple worlds, which Benford describes as "different sociopolitical categories of identity" that help each character-narrator to elicit understanding from the reader (328). Consequently, the reader may empathize with each narrator in turn despite their contrasting personal and moral agendas. In some ways, this structure could be tuned to making Frankenstein a wholly moral, socially accepted novel: understanding monstrosity from the inside yet still condemning it may serve to strengthen existing values.

For female readers, though, Frankenstein's ambiguous construction has additional ramifications. The layers of narration fracture the identities of characters and readers alike, revealing the parallels between fictional monstrosity and real-world challenges. Letters emphasize that the novel is about absent people and that the ability to write, read, and speak is a measure of a character's control over themselves and others. The characters that suffer the most in this regard are Elizabeth and the bride. Elizabeth is most strongly heard through Victor's memories or her letters to Victor, and in both cases, it is her absence that is felt most keenly. Elizabeth as a woman—one who lives and thinks and breathes throughout the day-is rarely seen by comparison. The bride is even more restricted; because she never lives, she cannot speak or write, meaning she has no claim to an identity or place in the world. For Victor and the creature, letters take on a more malleable existence that ultimately align them with their female counterparts. Victor's 
diary (a kind of letter to himself) is what reveals his existence and actions to the creature and sparks his wrath (Shelley 99). During the years the creature haunts Victor, his lack of letters makes his perceived absence worse: in one sense, he ceases to exist, but in another, he is more terrifying when missing. In the tundra, the creature truly turns writing against Victor, who says, "he left writing on the barks of the trees, or cut in stone, that guided me, and instigated my fury," which include instructions to find a "dead hare" so that he may "eat, and be refreshed" (160-1). The creature has fully reversed their positions: he writes and Victor does not, and he is in control and Victor is not. The creature's actions do not help him avoid death in the end, yet this step of regaining control is critical and a precursor to Cathy and Jane's success in later novels. As Frankenstein's characters have learned, the act (or abstention) of letter writing is fraught with dangers. It is also one that can be used to magnify control. The resulting uncertainty plays into the reader's response to Frankenstein's largest frame, Walter's letters to Mrs. Saville. Positioned as both free, external reader and the letter-recipient Mrs. Saville herself, readers are implicated in the same identity questions the characters face.

Blurring fiction and reality evoke gothic fiction's characteristic discomfort and naturally draw the reader into the extended, hidden critiques of how women view themselves. Parts of these critiques have been discussed before, such as when Sandra Gilbert and Susan Gubar take up Joyce Carol Oates:

a female artist in particular is keenly aware that she must inevitably project herself into a number of uncongenial characters and situations. It suggests, too, the degree of anxiety a literary woman may feel about such a splitting or distribution of her identity, as well as the self-dislike she may experience in 
feeling that she is "really closest to" those characters she "appears to detest." (69) At this point, the discussion is focused on female writers, but Gilbert and Gubar's term "literary women" leaves an opening for female readers as well. If "literary women" is extended to all women connected to texts in some way, then the anxiety writers feel may be extended to their readers as well. We may speculate that Shelley felt some connection to Walter, Victor, and the creature, but, perhaps more importantly, readers who feel the same way allow conversations about female identity to flourish. As the novel progresses, Walter and Victor come under additional scrutiny. How should readers judge Victor for agreeing to build the creature's bride, for instance, as well as his decision to destroy her? What about Walter's desire to learn more of Victor's dark scientific practices? Where once the novel projected these men as upstanding members of society, it now presents them with caution, even condemnation. Female readers may see themselves in these reversals, such as how a slip in public could lead to disgrace or secret thoughts may ostracize them from former companions. By encouraging the reader to connect to each narrator in turn, Frankenstein forces them to reckon with each type of monstrosity it presents: Walter's passive role as listener and potential for acting on his knowledge; Victor's fall from scientific potential to ambiguous moral choices; and the creature's parallel fall from a moral high-ground to vengeful murderer. The anxiety of connecting with or condemning each character may leave female readers questioning the novel's intent and their own personal identities. In this sense, readers may contribute to the "monstrous" nature of the book by giving additional life and real-world meaning to the people and themes that are otherwise confined to its fictionalized world.

Dreams also operate as a layer of control, mediating the relationships between the 
living and dead, text and reader with a dash of unnerving, gothic tension. Near the end of the novel, Victor's dreams become a lifeline: "During the day I was sustained and inspirited by the hope of night: for in sleep I saw my friends, my wife, and my beloved country" (Shelley 161). Coupled with their nourishing qualities, however, is their potential to consume him: "Often, when wearied by a toilsome march, I persuaded myself that I was dreaming until night should come, and that I should then enjoy reality in the arms of my dearest friends" (161). Victor's sense of what is "real" is unravelling. As the ghosts of his loved ones become more alive than the few beings he meets, he becomes more like a ghost in the real world as well, and his ability to influence the world decreases. Readers are implicated in similar feelings as the novel reinforces its demand for them to question the stability of their situations. Each element of the novel's gothic narration threaded with this theme of control, and its absolute failure to create or maintain stability extends to Frankenstein's female readers.

Female writers, too, are drawn into Frankenstein's sway. The creature's position as story-teller and created being make him a suitable stand-in for real female writers. He is created by a man only, his social position is determined by men, and his story is ultimately told through a foreign male proxy. Female writers encountered similar challenges because their male head-of-household could dictate their actions and men could take credit for their achievements-like Shelley experienced when Frankenstein was first attributed to men, including her own husband (Scott 614). In such a way, the creature and female writers both inherit their identities from the men around them and, for a time, this is stable. As the creature and women become more experienced, though, that stability breaks down. The creature reflects that an "increase of knowledge only 
discovered to me more clearly what a wretched outcast I was" (Shelley 99), and the same sentiment can be applied to women as well; it may indeed be simple to live with a constructed identity until its existence becomes known through personal trauma or (semi)public discourse, but after that point, adjusting to a new life becomes difficult and dangerous.

Victor's abandonment leaves the creature with an unsettled "childhood" that is an inadequate foundation for future success. When the creature first wakes, with his eyes "fixed" on Victor, he "muttered some inarticulate sounds, while a grin wrinkled his cheeks" and "one hand was stretched out" (Shelley 38). Even in his infancy, he reaches for Victor and what he represents: a creator, a mother, a family, and a guide. When he later reads Victor's journal and discovers his abandonment, he reads about his own "odious and loathsome person" (which he is now all too acquainted with) and Victor's flight on its account (99). He combines this understanding of what he is with the desirable "virtues" he learns from the De Laceys, thus determining that he can reconcile his physical deformity and mental acumen to gain a place in their society. This attempt, rooted as it is in the rageful identity Victor built and the compassionate one the De Laceys fostered, is destined to fail.

Despite being depicted as a physically masculine creature, the creature takes on a feminized demeanour, and his transition from a benevolent party to a vengeful one illuminates the risks to (and of) women who embody an identity handed down through social values. The parallels between the creature and real-world women begins in their early youth, with the main differences being the rate at which they learn and their memories of doing so. Shortly after being created, the creature learns what senses are and 
can later recount the experiences to Victor-something that real women would not be able to recall. Heiland describes the creature's "mind [as] a blank slate—John Locke's tabula rasa-on which sensations are inscribed" (103). Whether or not he desired to receive these early teachings, he did desire to continue learning when he met the De Lacey family, which Heiland categorizes as a kind of emotional learning (103-4). In addition to Heiland's sensory and emotional focus, the creature also learns what his "social nature" must be. He is aware that language creates a barrier to social acceptance:

I easily perceived that, although I eagerly longed to discover myself to the cottagers, I ought not to make the attempt until I had first become master of their language; which knowledge might enable me to make them overlook the deformity of my figure; for which this also the contrast perpetually presented to my eyes had made me acquaintance. (84).

His "blank slate" existence has allowed his surrounding world to teach him the basics of respectability. Knowing that he does not meet social expectations for appearance, he must compensate by showing strength in intangible culture — namely, language and learning.

The De Lacyes are unknowingly the architects of the creature's adolescence, developing in him the same intellectual and moral qualities as the De Lacey women. Charting the parallels between Agatha, Safie, and the creature reveals the impossibility of his happy adulthood. Agatha and the creature share a devotion to household duties and the comfort of the family. Before ever seeing her, the creature "arranged my dwelling, and carpeted it with clean straw" (Shelley 79), similar to how he later describes Agatha "arranging the cottage" (80). Agatha and the creature share the same intrinsic aptitude for household work. From this initial similarity, he grows to admire and learn from her. He 
observes that Agatha (and Felix) "placed food before the old man, when they reserved none for themselves" (82), and he, in turn, "abstained" from stealing their food and "satisfied myself with berries, nuts, and roots" (82). Through food, Agatha and the creature share a selfless deferral to the needy and to family hierarchies. All of their efforts are directed to alleviating suffering and maintaining a recognizable, comfortable home.

Safie is the model of a positive outsider, and her experiences in the cottage make it seem possible that the De Lacey family could accept the creature. She is marked by a different language, appearance, and race, much like the creature, and her lessons bring the hovel into the home and the domestic sphere. On a surface level, Felix teaches Safie world history; on a deeper level, he teaches her European values and world views. The creature absorbs them without question: he falls in line with racial labels like the "slothful Asiatics" and the "stupendous genius and mental activity of the Grecians" (Shelley 89). Although he shows some critical thought upon reflecting that "to be a great and virtuous man appeared to be the highest honour that can befall a sensitive being; to be base and vicious, as many on record have been, appeared the lowest degradation," he does not realize that what he learns is one specific kind of history and one set of values (89). Safie may well have recognized the differences between this education and her former one, but her calm demeanour prevents the creature from perceiving any tinge of confusion or regret. For his present goals of joining the De Lacey family, the creature's narrow understanding merely aligns him with the expectation for women to support the dominant values. He solidifies his position as a proper lady by turning away from an interest in war, government, and other masculine topics with "disgust and loathing" (90). The creature, as a blank slate, has successfully received the small education deemed necessary for his role 
as a domestic woman. He knows that evil exists in the world and that people must strive to be good.

Although the De Laceys have succeeded in creating a dutiful daughter, his simmering independence and physical appearance must still be reckoned with. Despite having the cultural capital to converse with the De Laceys and uphold their values, the creature's decision to demand their love and acceptance is a breaking point for his constructed identity, just as it is for their tranquil cottage life. Agatha and Felix's father, for instance, is at first persuaded by the creature's speech, encouraging him to reach out to the friends he describes (Shelley 102). However, as the younger De Laceys approach, the creature's carefully trained, respectful demeanour falls away, and he demands, "Do not desert me in this hour of trial!" His hold over the older man breaks, who in turn demands, "Who are you?" (103). The creature no longer has a claim to who he used to be; the version of him that lived in the hovel, devoted to study and household chores, has been replaced by one that is desperate, willing to fight for what he is owed. For their part, Felix, Agatha, and Safie don't need to hear what he told their father; his appearance is enough to cause them to fight, faint, and flee, respectively (103). Regardless of the identity they instilled in the creature, his physical appearance will forever bar him from their society. The creature burns the hovel in grief and rage (106) — not dissimilar to Bertha's final, fatal outburst against Rochester (Brontë 379-81) - but does not pursue the De Laceys. However, as Felix explains to their landlord, "The life of my father is in the greatest danger. . . My wife and my sister will never recover their horror" (104). These physical and mental ailments are the price they must pay for their role in making and unmaking the creature. 
Because they model domestic and intellectual pursuits as tools to improve family life, Agatha and Safie become recognizable representations of Victorian ideals. By extension, female Victorian readers would be able to empathize with the creature and imagine themselves living through his fate. The De Laceys' ultimate rejection of him warns about the frailty of his constructed identity and the futility of forcing a connection with a family. Moreover, it highlights the inadequacy of the terms "angel of the house" and "madwoman" for describing a young woman's initiation into a family's social structure. Both terms artificially limit his existence as a whole person: the former obscures his traumatic past and future ambitions, and the latter disconnects his physical rebellion from his constructed identity.

The creature's failed attempt to join the De Laceys also reflects poorly on Victor, who must now contend with the creature's need for vengeance and his own failings as a parental figure. In a sense, as an absentee parent, Victor optimizes the failed "angel of the house" that must remain accountable for his child's crimes. When he first meets the creature, Victor exclaims, "Why do you call to my remembrance circumstances of which I shudder to reflect, that I have been the miserable origin and author?" (Shelley 74). The immediate risk is psychological; "remembrance" and "reflect" show that he had attempted to forget his past actions, and yet the creature is there, like a long-banished ghost back to haunt anew. The creature's capacity to draw Victor into psychological distress - here as well as on the tundra later on — compliments his physical risk to other people. Victor is due a unique torment, one where life is worse than death, because he is the principle party responsible for creating the creature as he is. He gave him life, instilled the capacity for intellect, and discarded him. This tumultuous relationship 
between creator and created suggests that women with constructed identities are

primarily a threat to those who constructed them, with people on the periphery seen as collateral damage or even weapons. Victor's ultimate failing is his fickle devotion to creating the bride, an act that carried the potential for all involved to heal and rebuild but instead brought additional strife.

The creature's bride comes to represent women on the verge of marriage and the incredible degree to which a constructed identity can ruin a woman and her family. Elizabeth, too, fulfills this role, but she has stronger claims to a name, life, and death than the bride. As her only name and title, "bride" suggests she is an explicitly feminized being meant for one role. Intentions and reality do not always meet, though, and as Erin Hawley explains, she also has the "ability to function as a "boundary creature," one that is not quite creature, not quite human, that allows her to "disturb the boundaries" between nature and science (218-9). For Hawley, her fluidity explains why she captivates people and is reimagined through popular media. However, taken another way, it positions her as a character who has her identity made and unmade within the text itself. Her first identity as complicit bride is assigned by the creature, whose desire for her fuels much of the plot, suggesting that her absence is the most important practical challenge for him to overcome and for Victor to grapple with. With her, he believes he "can live in the interchange of those sympathies necessary for my being" (Shelley 111). He values her for the social, intellectual, and physical qualities that he expects a wife to have. When Victor refuses, he further laments that he must "now indulge in dreams of bliss that cannot be realized," while also acknowledging that he and his wife would "not be happy" but rather "harmless" (112). These inconsistent expectations foreshadow a problematic union 
because they commodify his bride and extend his own identity challenges to her, even while she is still an intangible fantasy.

Her second identity, one of a more willful bride, is even more assured of an unfortunate end. While recounting his rationales for not creating the creature's bride, Victor outlines the miserable existence of women with constructed identities and the potential for their misery to radiate to others:

I was about now to form another being, of whose dispositions I was alike ignorant; she might become ten thousand times more malignant than her mate, and delight, for its own sake, in murder and wretchedness. He had sworn to quit the neighbourhood of man, and hide himself in deserts; but she had not; and she, who in all probability was to become a thinking and reasoning animal, might refuse to comply with a compact made before her creation. They might even hate each other; the creature who already lived loathed his own deformity, and might he not conceive a greater abhorrence for it when it came before his eyes in female form? She also might turn with disgust from him to the superior beauty of man; she might quit him, and he be again alone, exasperated by the fresh provocation of being deserted by one of his own species. (Shelley 129)

On the most basic level, Victor understands that creating a woman solely to marry one man is a risky endeavour, in part because their shared "defects" could amplify the destruction the creature has already caused. More alarming to Victor, however, is her capacity for intelligence and desire for more than her pre-determined lot, which is more recognition to the strengths of women than many Victorian men would give. By accepting the bride as both a feminine creature and recognizing her ability to choose, 
Victor puts real women into the same situation: what happens when a woman is repulsed by who she is and what she is to become? Victor sees the risk in male terms. Given the creature's already murderous reaction to loneliness, the loneliness that follows rejection must be worse-like the years of vengeance that Heathcliff enacts after Catherine deserts him through marriage and haunts him through death. For real women, though, the risk is infinitely more personal. If they maintain the identities given to them, perhaps as a young woman also prepared for marriage, then they may be forced to halt their personal development and set aside their own interests in favour of their husband's. If they attempt to assert their own identity, the act may be misconstrued as a threat, even madness, such as both Catherine's and Bertha's experiences. For the bride-to-be, maintaining or dismantling a constructed identity is a dangerous endeavour.

The bride's third "identity" is the most problematic. In making and then unmaking her body, Victor symbolically makes and unmakes women as a social construct. As an absence, she provided hope for the creature and time for Victor. As physical entity, her existence is too great of a threat. Victor determines that she would fail at the role he designed for her and casts her into the ocean (Shelley 134). Her body, now in pieces, is left far from the original resting places of its parts. She becomes a truly Othered woman, unable to exist as either someone else's or her own creation. Since she never lived and thus could never act, the bride's fate is not truly a warning to other women. Instead, it is a warning to those who would use women in such a way. Victor must contend with the creature's wrath, much as a father may have to contend with an angered son-in-law. The creature must also face the reality that his own character and actions led to this point; even if he deflects blame to Victor, the bride's death is a result 
of what he made her. The authority that Victorian fathers and husband s hold over their female family members is not easily dislodged, and while Frankenstein stops short of providing a solution, it does alert women to the numerous ways their lives-and their challenges-are not wholly their own.

The creature's story ends with no successful marriages or stable lives. His legacy is not a recommendation for how to better oneself or society but a cautionary tale of the dangers and unhappiness tied to women who fail to find their own identities. The overall letter framework reinforces this point, as Mrs. Saville is never depicted with any great detail, making her, in effect, a named but blank slate woman that female readers can embody. By occupying her identity, female readers can engage with the events of the novel "firsthand," further bridging the gap between surreal gothic horror and their own lives. For other readers, though, Mrs. Saville may simply become a model Victorian woman and Frankenstein a moral tale about man's ambition. Ambition does, indeed, factor greatly into the characters experiences, and, as Beth Newman explains, "The price of failure is high. The results are violence and death, which, Frankenstein seems to suggest, lie somewhere beyond narration, as though narrative were a means of staving them off" (157). As long as a female character can keep a strand of narration going, as long as some bit of society or family life buffers her constructed identity, she can continue limping along. But, as soon as that last support falls away, her identity crumbles, and she is left a ruin. This is the experience of the first Catherine in Emily Brontë's Wuthering Heights, which continues the conversation that Frankenstein began. 


\section{CHAPTER 2: WUTHERING HEIGHTS}

Wuthering Heights (1847) by Emily Brontë explores the relationships of the Earnshaw, Heathcliff, and Linton families. These relationships are multifaceted, but their conflicts drive the novel's plot. When Mr. Earnshaw brings young Heathcliff into his home, he likewise brings in a dangerous outside influence, implied through his children's lost gifts, Heathcliff's unknown parentage, and his foreign appearance and language. From that moment on, the family is caught in a chaotic mix of love, jealousy, and revenge. Like the creature in Frankenstein, Catherine (Mr. Earnshaw's daughter) embodies the identities other people have constructed for her. Moving between Catherine Earnshaw, Catherine Heathcliff, and Catherine Linton, she demonstrates the profound risks these competing identities pose to her personal sense of self and the lives of those around her. When she dies in childbirth, she passes her struggles on to her daughter, also named Catherine (hereafter "Cathy"). Cathy works in the reverse order as her mother, moving from Cathy Linton to Cathy Heathcliff and, finally, to Cathy Earnshaw. While these versions of her conflict, she is able to recognize how her experiences have shaped her. By marrying Hareton Earnshaw and living at Thrushcross Grange as Cathy Earnshaw, she affirms the stable identity her mother sought but could not achieve.

Wuthering Heights's dual storylines fuel a dynamic range of scholarship that is nevertheless connected by its emphasis on the intangible. Gilbert and Gubar state that the novel "seems at times to be about forces or beings rather than people" (252). This line of thinking unifies Catherine and Cathy's experiences by making them less about their 
individual choices and more about the driving factors behind them, including supernatural fate (like Catherine and Heathcliff's shared souls reuniting as ghosts) or social pressure (like the need to be a good child or wife). It also connects to the critique of the heroines' personal success; Steve Lukits pairs Catherine and Cathy's fates—one dead and the other "domestically compromised"- to argue that "their rebellion is suppressed" (115). That is, the forces of life/death and social rebellion/acceptance are ultimately brought to bear, with death and acceptance winning out. Another, more narrative force lies within the novel's structure. Lorraine Markotic argues that Cathy's life allows Heathcliff to "live and to act, and he ultimately acts in accordance with Catherine's desire. His desire is aligned with hers, and only when it is fulfilled is he ready to die" (88-9). Taking Cathy's story as a tool to finish Heathcliff's makes her even more subordinate to him than she was as his trapped daughter-in-law. Within these discussions, Catherine and Cathy's internal forces are downplayed. However, regardless of whether they are deemed "successful" or "independent" in the end, both women actively engage with the people and passions that shape them. Following their efforts sets them apart from other people (and each other) even as they are forcefully brought together by the winding halls and pages of Wuthering Heights.

Like Frankenstein, Wuthering Heights is built around layers of narration and familiar gothic motifs. Mr. Lockwood takes Walter's place as an interested, yet dutiful, listener and recorder; his document contains Nelly's account and Isabella's letter, and through them, Catherine's diary, Cathy and Linton's letters, and an assortment of other written and verbal artifacts. The resulting structure blurs the line between past and present, allowing the juxtaposition of Catherine's and Cathy's relationships, identities, 
and future prospects. Most of the narration is fixated on conflict, with happier years being skipped entirely. Ingrid Geerken contends that this prevalence of grief makes the novel about the "temporal and libidinal process of putting together what has broken apart" (378), a process that can be likened to restoring what once was. However, no lives or relationships are put back together in any way that resembles their prior forms. More than being about repairing, then, it is about acknowledging the old while creating the new. The novel, as a collage of distant and recent past events, is a kind of new object crafted from old things. In the same way, Catherine's fractured identities are based on old influences, and Cathy's eventual positive future is built on her (and her mother's) past sufferings.

Through diaries, letters, and books, the inner struggles of Catherine, Cathy, and Isabella are made public: Catherine writes to explore her potential identities, Cathy's varying access to letters and books halts her personal development, and Isabella lives and dies through letters. In this way, writing physically connects the living to the dead, the present to the past. Catherine's identity crisis is introduced when Mr. Lockwood discovers her names "scratched on the paint" of her panelled bed: "This writing, however, was nothing but a name repeated in all kinds of characters, large and smallCatherine Earnshaw; here and there varied to Catherine Heathcliff, and then again to Catherine Linton" (Brontë 13). Dismissive at first, he is quickly overwhelmed "when a glare of white letters started from the dark, as vivid as spectres - the air swarmed with Catherines" (13). The carved names are a visceral kind of writing that demand his respect. The ghostly vision of Catherine's names and the too-conveniently timed candle accident (which itself reeks of death, this time "roasted calf-skin") lead him to her diaries, which are written in the appropriated white spaces of other books belonging to 
"Catherine Earnshaw" (13). This early, brief encounter with Catherine's belongings demonstrates, as Patricia Crain remarks of $19^{\text {th }}$-century texts more generally, that “children's appropriation of their books exceeds the instrumental; their exuberance commands the space of the book as a collaborative canvas, a treasure cache, and an external self ... when children died such books were marked 'in memoriam' by parents or friends, adding to the haunted and haunting quality such artifacts retain" (15). By carving her current and potential names into the wood, Catherine tests what it would be like to embody that identity outside of her own mind. Her diaries are strictly owned by Catherine Earnshaw, suggesting that they are a closer representation of her internalized sense of self; whoever she may be on the outside, she remains an Earnshaw. Once she is dead, they are also a way to reconnect with her, for while they may not have been marked as "in memoriam," they are directly tied to Mr. Lockwood meeting (or at least dreaming of) her distraught ghost. Heathcliff's presence is certainly one reason why she remains in Wuthering Heights, but as texts, the wood engravings and bound diaries continue to occupy her room and give her ghost additional ownership over its space.

Cathy has no such claim to life or space through text. She has no true diary and instead expresses herself, variably, through letters, carvings, or speech alone, a situation that hampers her opportunities for self-exploration. Rebecca Steinitz explains that "In the novel ... the diary itself becomes the proverbial place of one's own, but its very status as such reveals how, psychologically, textually, and materially, one's own place can never be secured" (408). The absence of a diary for Cathy magnifies the restrictions on her identity formation and physical being. For much of the novel, she does not have a "secure" space — either within Thrushcross Grange or Wuthering Heights—where she is 
able to exist without scrutiny. Her early attempts at letter-writing fail when Nelly finds the stash of letters from Linton, but more interestingly, all Nelly reveals about Cathy's writing is that it is "affectionate... more simple and more eloquent than her cousin's, very pretty and very silly" (Brontë 166). Whatever persona Cathy adopts in these letters is obscured by this remark, and it sets up her troubled relationship with writing going forward. When Mr. Lockwood delivers a letter from Nelly, he sees Cathy "carve figures of bird s and beasts, out of turnip pairings in her lap" (219). Her focus on creatures rather than text distances her from Catherine's youthful writing as if she is not even attempting to explore her sense of self and how it fits into her wider world. She also explains that "I have no material for writing, not even a book from which I might tear a leaf" (220). She is completely removed from the identity-making process writing affords and remains confined within Wuthering Heights and her own body. Her books resurface, at first just to be burned (222). Later, though, they facilitate a mutual "rebuild ing" of Cathy and Hareton's relationship and outward personalities; teaching Hareton to read gives Cathy authority as well as a calmer demeanour, and learning to read gives Hareton social mobility and a closer equality to Cathy (228). In reclaiming her right to a reading community, Cathy reclaims her own voice.

Isabella is, perhaps, less lucky than either Catherine or Cathy. Her letter to Nelly, written after marrying Heathcliff, shows that her desire to be Isabella Heathcliff has evaporated, yet her former self, Isabella Linton, cannot be reclaimed. Although she does not detail all of the domestic abuse, it is clear from her asking if Heathcliff is a "man" or a "devil" that her new home is neither comfortable nor safe (Brontë 100). Judith E. Pike argues that the letter would be "unorthodox" for its time because it "violates the celestial 
and romantic image of the honeymoon and its defining moment of a young lady's transformation from girlhood to womanhood and her entrance into her domestic role as lady of the house" (354). Isabella does go through this transformation, but she does so in a way reminiscent of the creature's bride, shifting between the potential to exert her independence and the potential to be subsumed by her husband. Early in the letter, she states that "she must write to somebody, and the only choice left to me is you" (Brontë 100). The critical nature of writing the letter recalls the importance of writing for both Catherine and Cathy, and Isabella's ability to write now, despite her situation with Heathcliff, suggests that Isabella Linton still exists in some capacity. Indeed, Isabella Heathcliff does not seem to truly exist because she introduces herself to Joseph by saying, "My name was Isabella Linton . . I'm lately married to Mr. Heathcliff” (101-2) and signs her letter as just "ISABELLA" (107). Pike reads these instances as a potential acknowledgement of her precarious legal situation (358), but it extends to her inner turmoil as well. She is conscious of losing her name and identity and the inability to become "Isabella Heathcliff," which is exasperated by "Heathcliff" standing for both his "Christian and surname" (27); more so than other married names, hers necessitates a kind of "becoming" him as a person, which only Cathy, who shares a soul with him, seems capable of doing. Consequently, Isabella's identity is in flux-no longer a Linton yet not a Heathcliff, either. Although she does display some elements of domesticity later on, such as bearing Heathcliff an heir, that, too, collapses: she flees Wuthering Heights and raises a frail child (135). The shifting names and unhappy union implied in the letter capture the fear and regret that accompany a mandated identity shift.

Letters are not the only gothic elements within Wuthering Heights-the novel or 
the house. Consistent imagery of ghosts, windows, and wind add to the gothic horror of Catherine and Cathy's lives. Catherine's appearance as a ghost at the window is, of course, an example of a haunting (Brontë 18); but Cathy, too, has ghostly qualities. When sneaking back into Thrushcross Grange after visiting Wuthering Heights, Cathy "entered by the casement-window of the drawing room, and glided noiselessly up to where [Nelly] awaited her" (181). Her ghostly persona contrasts her mother's: Cathy is quiet where Catherine is loud, and the window lets Cathy in but locks Catherine out. As a more subtle ghost, Cathy can move within the house and around its inhabitants, an ability that resurfaces when she cares for Linton. She realizes that "my presence is as potent on his nerves, as a ghost; and I fancy he sees me often, though I am not near" (210). These descriptions turn her into a kind of living dead, a corporeal counterpart to Catherine's ghost. These parallels continue with the weather, as both have an affinity for wind. When ill, Catherine longs for her old room and "the wind sounding in the firs by the lattice. Do let me feel it—it comes straight down the moor—do let me have one breath!” (91). When Edgar is ill, Cathy finds comfort in "her breeze-rocked cradle" in the trees (169). The wind changes, with storms accompanying bad days and breezes good ones, turning the weather into an extension of their inner selves. Interwoven as they are throughout the novel, ghosts and wind give a sense of perpetual presence and supernatural power to Catherine and Cathy, causing them to haunt the pages in their own ways.

Catherine's life is characterized by her attempts to reject influences that control her and accept those that benefit her desires. Unfortunately, because her traits are poorly balanced (more of a reversal of power than true integration), she is pained by the loss of her selfhood and loved ones. Her identity formation is influenced by her relationships 
with her father (Mr. Earnshaw), Heathcliff, and Edgar Linton, all of whom all provide her with a difference sense of self: the headstrong child, passionate lover, and devoted wife. Their influences are reinforced by Hindley and Joseph, who rebuke her passions in the other men's absences. As a child, Catherine Earnshaw is known for her domineering will, and while this trait irks her father, he is instrumental in creating it. In the earliest scene of Catherine's childhood, Nelly recollects that, "on a fine summer morning," Mr. Earnshaw asked his children to pick out gifts for themselves. Catherine "could ride any horse in the stable, and she chose a whip" (Brontë 25). The weather casts this interaction in a positive light, suggesting that Catherine's want and ability to control is desirable, even if it is only over horses. At "hardly six years old," her choice is also telling of how ingrained this trait is (25). However, when Mr. Earnshaw returns with Heathcliff instead of the whip (it was lost), she "showed her humour by grinning and spitting at the stupid little thing, earning for her pains a sound blow from her father to teach her cleaner manners" (27). The characteristics that Mr. Earnshaw so recently fostered now lead directly to punishment, reducing Cathy to what she should now become: an obedient daughter. Instead of accepting that new role, she continues as before, though now she turns to affection to get her way and make amends. In one such moment, her father responds, "I cannot love thee; thou'rt worse than thy brother. Go, say thy prayers, child, and ask God's pardon. I doubt thy mother and I must rue that we ever reared thee!" (30). He recognizes his role in constructing this version of Catherine and yet does little to unmake it. She "hardened," learning to laugh at, not listen to, those who corrected her (30). This behaviour remains with her throughout the rest of her life, though it is sometimes subdued. In the beginning, it makes her a fair match for Heathcliff's independence, and in later years, it contributes 
to her pitting Heathcliff and Edgar against each other.

Heathcliff's early hold over Catherine is not as explicit as her father's. In their youth, Heathcliff may not have intended to influence her identity formation at all, but that does not negate his effect on her. Thomas J. Jourdrey points out that "Heathcliff treats Catherine as indistinguishable from his own self," making his love for her a kind of "narcissism" (180). Taken another way, his inability to see her as a separate human being explains why he is, initially, more passive. Catherine's turn towards Heathcliff is quick; Nelly does not explain how she overcame her aversion to him, but after her punishment, the line between them fades. When her brother, Hindley, banishes him from the house, she becomes his teacher and helps with his chores (Brontë 33). Through these activities, she begins to literally follow Heathcliff, an act that is a precursor to her spiritually following him as well. Around this time, they walk to Thrushcross Grange to spy on the Lintons, which is the first time they are described with ghostly qualities, being "invisible" when Nelly attempts to find them (33). While meant physically, Nelly's comment also marks the moment when Catherine's former Earnshaw identity slips away. Indeed, she becomes something of a ghost at Wuthering Heights, as the dog bite on her ankle prevents her from returning home (37). From here, her physical closeness to Heathcliff lessens even as their spiritual closeness increases. Like Heathcliff, Catherine believes that there is no meaningful division between him and her: "Whatever our souls are made of, his and mine are the same" (59). Sharing souls eliminates any divide between them, effectively nullifying Catherine's unique sense of self. The whip was once her icon, a symbol of her ability and drive to control, and that is now undermined by merging with Heathcliff. 
Stricken of her independence and separated from Heathcliff, Catherine becomes susceptible to other influences, primarily from the Lintons, and gradually mirrors their behaviours. Upon being discharged from Thrushcross Grange, Heathcliff observes that "She sat quietly on the sofa" while receiving medical treatment, food, drink, and other comforts that made her "as merry as she could be" (Brontë 36-7). The combination of her silence and the uncertain extent of her merriment may imply that she suffered in silence, daring only small displays of displeasure, like pinching the dog's nose. However, Heathcliff's generally positive tone, ending with how she is "immeasurably superior" to the Lintons (37), makes it more likely that she enjoys being doted on once more, as her father had done with the promise of a whip. This gives Edgar an opening. After accepting his marriage proposal, Catherine tells Nelly that she loves him because "he is hand some," "pleasant to be with," "young and cheerful," and "he loves me" (57). In these descriptions, Edgar is the opposite of Heathcliff but the perfect compliment to her newly refined social persona. She adds that "he will be rich, and I shall like to be the greatest woman of the neighbourhood, and I shall be proud of having such a husband" (57). More than his personal qualities, Catherine is drawn to the benefits of what Talia Schaffer calls a "familiar marriage": "relationships," "security," and "communities" (x). Marrying him provides the opportunity for Catherine Linton to be whole, possessing all that she believes she needs for a stable, contended life. She also recognizes that, to a degree, her relationship with Heathcliff is incompatible with her new life: "it would degrade me to marry Heathcliff now," and she resolves that "he shall never know how I love him" (59). Her acceptance blocks out the potential to be a Heathcliff, legally confining her to Thrushcross Grange more surely than any injury could — even if she does not realize it. 
Throughout this time, Catherine poorly negotiates these mixed identities. Upon returning Wuthering Heights, Catherine experiences the first of many clashes between her soul-bond to Heathcliff and her social desire to be a Linton. Her reformation as a "very dignified person" and Heathcliff's neglected state make him look "black and cross," a point he takes offense to (Brontë 37-8). She cannot see how her new demeanor and friends are ill-suited to Heathcliff and the relationship she believes they maintain. Instead, she attempts to be both the woman the Lintons made and the passionate girl that follows Heathcliff, to the detriment of both. A few months later, she is infuriated by Nelly and Hindley, and Edgar attempts restore order by grabbing her hand. She slaps him for his efforts, making him "afraid, and ashamed" of her (51-2). This time, her new habits give way to her earlier Earnshaw dominance, showing that even subdued elements of her past self are not truly gone. She has failed to become any of the Catherines known so far: an Earnshaw daughter, Heathcliff's soulmate, or a Linton copy-cat.

Although the now-married Catherine Linton falls in line with Edgar's expectations, her former selves need little provocation to reappear. Nelly explains that "she behaved infinitely better than I dared to expect," helped along by Edgar's efforts to avoid "ruffling her humour" and thus preserve her model wife behaviour (Brontë 67). Almost in the same breath, Nelly describes her as "gunpowder [that] lay as harmless as sand" and that she had "seasons of gloom and silence" (67), aligning passivity with ailment. Legally becoming Catherine Linton has sealed off the potential to be anyone else: she cannot return to Wuthering Heights as an Earnshaw or run away with Heathcliff. The inflexibility of this position becomes the catalyst for the illness that overtakes her. As soon as Heathcliff returns, she becomes "breathless and wild" like her younger self, and 
her passions cannot be contained (69). After her attempts to bring Heathcliff and Edgar together end in physical conflict (82-3), she is confronted by her double life, first determining to "try to break their hearts by breaking my own" (86) and then asserting to Heathcliff that "You and Edgar have broken my heart ... you have killed me" (117). These rapid relationship changes break more than her heart. Her sense of self breaks down as her illness progresses, to the point where she fails to recognize her reflection in a mirror (90). Living as Catherine Linton was impossible when her passions for Heathcliff were reawakened, and surviving was possible only if she could access both of her selves by controlling Heathcliff and Edgar. Once the men fight again, making the co-existence she longed for impossible, she is unable to return to being just a Linton and even more incapable of forging a new path. Her mental break and bodily death are the product of a shattered identity that can no longer maintain the semblance of a single woman.

Even in death, Catherine cannot be whole. Heathcliff calls to her, saying, “Catherine Earnshaw, may you not rest, as long as I am living!” (Brontë 124). By revoking her Linton name, he frees her ghost from Thrushcross Grange and tethers it to Wuthering Heights and himself. Her burial spot, too, leaves her unsettled. She is buried "neither in the chapel, under the carved monument of the Lintons, nor yet by the tombs of her own relations, outside." Instead, she lies "on a green slope, in a corner of the kirkyard, where the wall is so low that heath and bilberry plants have climbed over it from the moor; and peat mould almost buries it" (124-5). The position gives the moor a greater claim to her than either the Linton or Earnshaw families can muster. She finally distances herself from them, though the low wall contains her in the region. Likewise, Heathcliff is present through the intrusion of the plants, foreign bodies creeping towards 
Earnshaw and Linton land. The plants also reflect Catherine's mobility as a ghost, which continues to follow Heathcliff through Wuthering Heights and across the moors. When Edgar and Heathcliff do join her here, they are equally separated from their families, symbolizing the decline of their conflict and a new beginning for Cathy and Hareton.

Before she can reach that new beginning, Cathy must survive the transitions between her Linton, Heathcliff, and Earnshaw identities. Cathy Linton is, perhaps unsurprisingly, her father's creation. The troubling aspect of his parenting style is not how stern he is, like Mr. Earnshaw was with Catherine, but how much he shelters Cathy. As with her mother, Edgar ensures that the servants do not upset her (Brontë 139), only instead of controlling an ingrained Earnshaw-dominance, he nurtures it. Giving Cathy free rein over the servants and Thrushcross Grange's land builds what looks like independence: a stubborn drive to obtain what she wants. It is not a whole independence, though, because it is not built on whole truths. As he would later describe it, Edgar kept Cathy's family history a secret "for her own good" as protection from Heathcliff (164). However, without knowing that Wuthering Heights exists, what Heathcliff did, and what her mother was like, Cathy is woefully unprepared for the outside world, and Penistone Crags in particular. She explains to Nelly that "I know the park, and I don't know those" (140). The statement goes beyond showing the allure of adventure and connects Cathy to her mother, father, and Heathcliff; years ago, Joseph's trip to Penistone Crags left Catherine alone, and the ensuing disputes made Heathcliff leave and Edgar propose. The Crags are just as fateful for Cathy. In an attempt to reach them, she is stopped at Wuthering Heights and forms a favourable impression of Heathcliff that must be unmade by Edgar's account of her aunt's marriage (164). With her isolation shattered, Cathy is 
"so deeply impressed and shocked at this new view of human nature ... that Mr Edgar deemed it unnecessary to pursue the subject" (164). Unfortunately, seeing Heathcliff's darker side does not teach her how to look for it in others or to assess the risks of other acts (like writing to Linton). Through his overprotective approach, Edgar creates a young Cathy that is perfectly attuned to fall for Heathcliff's revenge plan.

Cathy's transformation into a Heathcliff is a gradual, if perpetually unstable, experience. She is influenced by both Linton and Heathcliff, and their dual efforts are most clearly seen in Linton's early letters. Nelly describes them as "foolish as the age of the writer rendered natural, yet with touches, here and there, which, I thought, were borrowed from a more experienced source" (Brontë 166). The combination of Linton's and Heathcliff's writing makes Cathy fall in love with a person that does not exist. In turn, the version of her that loves the writer is a kind of fallacy, or fantasy, that cannot survive beyond the letters. Indeed, it does not seem able to survive a single meeting with Linton: she tells Linton she loves him but not his father, and then a moment later that she hates him, owing to a dispute about whose father was lying (175). Before she leaves, she and Linton are back on good terms, and she is adamant that she can make her own choices about her relationship because "I'm almost seventeen. I'm a woman" (178). This proclamation puts her on the precipice of an identity change; like the creature's bride, she must face the transition that accompanies her position as a bride-to-be. After she is married, Linton keeps her confined and complains that she "cries" and insists on "moaning and grieving, all night long" (205-6). In part, Cathy fears for her father, who is ill; but she also laments the loss of her former life. Her personal grief only increases after Linton dies. Speaking to Heathcliff, she says, "He's safe, and I'm free ... you have left 
me so long to struggle against death, alone, that I feel and see only death! I feel like death!" "Freedom" here is relative, as she is still legally a Heathcliff, even if her husband is gone. Feeling "like death" suggests that her Linton and Heathcliff identities are crumbling, leaving her to mourn her own ghosts.

Becoming Cathy Earnshaw allows her to accept what she has lost without forgetting it or being haunted by it, including the freedom lost by marrying Hareton. Hareton nurtures her sympathetic side by explaining that "he'd rather she would abuse himself, as she used to, than begin on Mr Heathcliff." The "sorrow" she feels at having ever upset Hareton is profound (Brontë 236), and she never tests his patience—-something she would have done with others in previous years. Cathy Earnshaw, then, has elements of Cathy Linton's "heart, sensitive and lively to excess in its affections" (139). Hareton does not demand the exuberant passions that connected Catherine and Heathcliff, and the quieter traits he looks for in Cathy do not confine her. Nelly implies that Cathy would still speak negatively of Heathcliff if Hareton was out of earshot, so she has not allowed him to dictate her actions or thinking (139). Indeed, she can also steer his actions, such as when she has him dig up Joseph's beloved currant bushes (232-3). She is devoted to him, but not subservient. In this sense, she deviates from her mother's "familiar marriage," choosing, instead, one with a more balanced scale of sacrifice and respect.

Together, Cathy and Hareton end the chapter of her life written by Wuthering Heights. The Heights must be abandoned because it still belongs to Catherine and Heathcliff, who remain to haunt it (Brontë 247), and Catherine still possesses her belongings and former bedroom. If Cathy stayed, two Catherine Earnshaws would compete for the same space, and as an Earnshaw or Heathcliff, she was always a visitor 
(or inmate) in her mother's home. The fact that Cathy Earnshaw can leave while Catherine Earnshaw cannot also suggests that only the former can continue to exist without it. Cathy may still carry memories and traits influenced by Edgar and Heathcliff, but because they are recognized — not suppressed, like they were with Catherine - they are unlikely to resurface with anything like their former vehemence.

Their marriage does still present some potential risks. It is still based on a Linton bringing an Earnshaw to Thrushcross Grange, and Catherine's breakdown and death at the Grange is never addressed. Leaving Wuthering Heights becomes a symbolic act of walking away from the negativity in their past lives, and while it seems probable that they will remain a loving couple, it may take many more generations before their family has fully moved on from the Earnshaw-Heathcliff-Linton conflict. As a couple, Cathy and Hareton are selective about the people who will live with them, choosing to bring Nelly and exclude Joseph, who remains at the Heights with the ghosts. Heathcliff's return is what led to Catherine's fatal illness, and their lingering ghosts mean that their influence lingers as well, perhaps explaining Nelly's fear of them, which even she recognizes as "nonsense" (Brontë 247). Remembering the past is critical for Cathy and Hareton moving forward; if they forget what they survived and how they changed, Catherine and Heathcliff are close enough to remind them with potentially catastrophic results. Nelly and Joseph's positions at the Grange and Heights also match where they were during Catherine's last days, suggesting, once again, that the past may be repeated.

With its two main couples "present" (if not alive) at its close, Wuthering Heights echoes the ending of Frankenstein while also following with its own call. Catherine's story is characterized by attempts to control the uncontrollable. Mr. Earnshaw, Heathcliff, 
and Edgar all attempt to restrict her to their perfect image and only succeed in creating a fragile surface with an even more fragile core. When faced with adversity or reminders of her former selves, Catherine's surface personality fractures, and her other internalized identities re-emerge. Once released, she makes the men share her torment. Mr. Earnshaw grieves for the good daughter he cannot have, Heathcliff is bound to a Victor-esque torment complete with ghosts and a longing for death, and Edgar loses everything — wife, daughter, and sister. Catherine's, Edgar's, and Heathcliff's neighbouring graves and Catherine and Heathcliff's haunting suggest bring a semblance of peace yet no resolution, an ending comparable to Frankenstein, where Victor's and the creature's deaths conclude their living story but not the living, letter-based one Walter has created.

Wuthering Heights offers Cathy's story as an alternative to Catherine and the creature's, though it, too, does not provide a concrete conclusion. Like her mother, Cathy slips between identities that Edgar, Heathcliff, and Hareton construct; unlike her, she sees past these constructions and builds her own sense of self, accomplishing what Sarah Ahmed describes more generally as “moving on": while not fully resolved, past trauma does not dictate her future (38). Part of this process involves remembering the past to avoid "a repetition of the violence" (34), which Cathy does by accepting Hareton's affection for Heathcliff and by leaving Wuthering Heights. As a result, her future prospects are decisively better than those of Catherine's ghost. And yet, the novel's ending makes the materialization of those prospects uncertain, thus leaving the conversation about identity unfished as well. Jane Eyre takes up the next role as speaker to expand on the lives of women like Cathy; where Cathy's self-affirmation is brief, encapsulated by the novel's last pages, Jane narrates the full extent of her experiences. 


\section{CHAPTER 3: JANE EYRE}

Taking the discussions about female identity in Frankenstein and Wuthering Heights a step further, Charlotte Brontë's Jane Eyre (1847) critiques Victorian perceptions of female selfhood and what it means to be made by others. In Jane Eyre's case, "constructed identities"—versions of Jane that are created by people that influence her - are overtly problematic, and she continually discards them. For instance, Mrs. Reed (and later Mr. Brocklehurst) attempts to turn her into a problem child under the guise of discipline; Jane rejects the "problem child" identity and begins to work towards a new one at Lowood. Her friend Helen Burns and teacher Miss Temple help her adapt to being a student and then a teacher, and while she succeeds in cultivating traits that attract companionship and respect, her identity cannot be sustained without their support. Similar situations occur with Edward Rochester, her employer and love interest, who tries to turn her into a mistress and an aristocrat, and with St. John Rivers, her cousin, who intends to make her a model missionary's wife. Diana and Mary, also cousins, contribute in more positive ways by providing a welcoming female community, but the identity they support is fragile. While tempted to commit to some of these roles, Jane consistently weighs the pros and cons of doing so, and choosing to be "Jane, who married Rochester" (she never calls herself "Jane Rochester") is the final step towards affirming her own identity. While her socially atypical marriage to Rochester takes away some of her social and personal freedoms, it does not fundamentally change her. Therefore, Jane Eyre completes the conversations started in Frankenstein and Wuthering Heights by presenting 
Jane as a woman who successfully vets the influences of others and blends her experiences into her own final, stable identity.

Jane Eyre has always been at the heart of gender discussions such as this. Initial reviews paralleled those for Frankenstein and Wuthering Heights and included debates about the author's gender and the text's "immoral" content ("Jane Eyre: An Autobiography" 9; Rigby 506). In the twentieth century, feminists used it to define present-day gender inequality, and it was perhaps most notably used by Sand ra Gilbert and Susan Gubar as the premise for the Madwoman in the Attic (1979). Within this feminist scholarship, Adrienne Rich, among others, comments on the novel's appeal to modern readers: "I have never lost the sense that it contains, through and beyond the force of its creator's imagination, some nourishment I needed and still need today" (142). In the context of gendered identity discussions, "nourishment" becomes the connection between present-day women and past women - the creation of a timeless community of women speaking to women. More recently, Cheryl A. Wilson identifies reading as a specific act that brings women together: "Charlotte's attention to the act of reading is not only important for her characters, but also for her readers, who can see their own actions mirrored in those of Charlotte's reading women" (138). As with other female gothic novels, Jane Eyre shows women that they are not alone in their experiences, fears, and desires and gives them access to a wealth of shared knowledge. These connections are not limited to the novel's initial readers; they remain in the present, with women continuing to find themselves and each other through Jane and her contemporaries.

It is somewhat problematic, then, that Jane Eyre as a woman is sometimes lost in scholarship even when her relevance to modern readers is maintained. Speaking of the 
relationship between the sublime and the uncanny, Donna Heiland explains that "the uncanny confronts the subject with something long repressed or forgotten ... the person is literally or figuratively 'haunted' by this reminder of a past that she cannot identify and cannot escape" (6). This idea of an intangible, haunting past applies to the way Jane (and Betha) have been imagined and reimagined as different things, including as an "angel" or a "madwoman." Being conscious of how one reading builds on another is critical; losing sight of (or forgetting) the past can lead to the kind of "haunting" Heiland mentions here, where unresolved concerns continue to exist on the margins of new ideas. For instance, Brian Wilks's reading of Jane Eyre effectively argues a thematic point but misses the novel's gendered and racial themes: "Jane Eyre champions the ordinary human beings, claiming the right of all to be considered, heard, and respected," (285). Making Jane an "ordinary human being" with no unique features homogenizes individuals, thus obscuring her claim to womanhood and her connection to female readers. It also hides her (and Brontë's) status as a white British citizen, further complicating the position Jane Eyre occupies as a colonial text. Analyzing "the problem of split-ness in Jane's voices," as Daun Jung describes it, adds another layer to this issue. Jung's intent is to better understand how the editorial "Currer Bell" voice interacts with both young Jane and the older, narrating Jane. However, the emphasis on "splitting" Jane into different parts and the "problem" it creates turns her into several voices that, when forced to stand on their own, obscure her complex character. Another option is to recognize these different voices as elements of a single whole: they diverge and converge at different points in the novel to demonstrate Jane's realistic growth as a human being. Moving forward, it is important to reflect on how past decisions impact present and future ones, in terms of the 
characters' own stories and the broader literary narratives they are brought into.

The gothic motifs throughout Jane Eyre draw the characters and readers together, amplifying the feeling that both are haunted. Like the creature in Frankenstein and the ghosts of Catherine and Heathcliff in Wuthering Heights, the madwoman is a nearsupernatural being that stalks, haunts, or otherwise threatens those that society deems sane. In Jane Eyre, this role is primarily given to Bertha Mason Rochester, Rochester's first wife. She is mentally unwell and secretly locked in his attic, escaping at opportune moments to impede Jane and Rochester's relationship. Often identified as Jane's "double," Bertha can act as a reflection of Jane's inner self (Campbell 241; Gilbert and Gubar 360). She has also been approached as a stand-in for all women, such as when Gilbert and Gubar use her to articulate "a common, female impulse to struggle free from social and literary confinement through strategic redefinitions of self, art, and society" (xvi). The madwoman, then, operates on multiple levels: she brings a fear of the self and the unknown into female gothic narratives and emulates the readers' struggles.

Like gothic madwomen, gothic children have grim prospects that follow them even into adulthood. Jane is orphaned in her youth, but the trouble of the "missing mother" is only the start. Lucie Armitt notices that "Repeatedly, the Gothic girl child must undergo trauma on her journey towards womanhood ... If Moers is right and the Gothic especially offers its heroines adventures they cannot find elsewhere, the price it seems they must pay for having them is learning to go it alone" (71-2). Jane certainly does "go it alone" when she is locked in the (possibly) haunted red room and makes all of her journeys unaccompanied in a public carriage. She is also alone when she hears Bertha for the first time (Brontë 98) and when Bertha tears her wedding veil (254). In most of 
these cases, being alone creates obstacles, such the risk of dying form starvation and exposure after leaving Thornfield (295). However, solitude is also a refuge and cause for self-discovery, notably when Miss Temple's departure from Lowood gives her the motivation to be more than a student or teacher (78-9). Although not precisely a "child" for most of the novel, she is not a full adult, either, and cannot be until she has neg otiated her own identity - in some sense, until she has written the own ending to her book. The juxtaposition of the risks and benefits of being a single, isolated woman allows for a more intimate understanding of Jane as an individual set apart from those who influence her.

Supernatural transformations stitch these gothic elements (and the characters) together. Jane's very first meeting with Rochester is remarkable for Rochester, his dog, and his horse transforming from frightful spirits to ordinary creatures (Brontë 103), and when he is maimed by the Thornfield fire, he "transforms" in the sense that the fire “enhances any physical monstrosity he may have already possessed" (Campbell 238). These scenes contain the most prominent supernatural imagery, but the supernatural appears more subtly as well. As she returns to Thornfield after Mrs. Reed dies, Jane sees Rochester sitting outside and thinks, "Well, he is not a ghost; yet every nerve I have is unstrung” (Brontë 219). Rochester's ghostly qualities align him with Cathy when she frightens Linton, though Jane is moved by affection, not discontent. And, of course, Bertha's wailing and sequestered existence make Thornfield feel haunted even if the denizen in question is still alive (98). This imagery reappears when Rochester calls for Jane across the moors, and she hears him leagues away at Marsh End (374). Whether from mythical spirit to human, living to dead, or corporeal to incorporeal, supernatural transformations surround Jane as she, too, transforms from one Jane into another. The 
transformations are never fully explained-were they real or superstition, as Jane wondered?-yet the lack of definite conclusion does not render them inert. In the same way, Jane's happy ending does not necessitate a neatly defined identity. Rather, it needs one that is more stable than the whims of a spirit yet malleable enough to allow growth. As a young child, Jane must learn to separate her true self from the assessment of Mrs. Reed and her children. The novel opens with Mrs. Reed scolding Jane: Until she heard from Bessie [her daughter] and could discover by her own observation that I was end eavouring in good earnest to acquire a more sociable and child like disposition, a more attractive and sprightly manner-something lighter, franker, and more natural, as it were-she really must exclude me from privileges intended only for contended, happy, little children. (Brontë 9) The desirable qualities that Mrs. Reed focuses on- "sociable and childlike" and "more natural" in particular - turn Jane into a kind of reclusive "monster," one that lacks any resemblance to a well-behaved human child. The following question of "What does Bessie say I have done?" emphasizes the uncertain reliability of Bessie's narrative, not of the traits Jane has been given. At this point, Jane accepts her banishment to the other room, and with it, the role of problem child. However, she quickly learns to continue searching for her identity and place within the family, asking if she is her cousin's "servant" and learning that she is "less than a servant, for you do nothing for your keep" (14). Classified as a "monster" and cast out from family and servant circles alike, Jane is trapped at Gateshead until she realizes that she must find, and advocate for, her selfhood.

The residents of Gateshead push Jane's tolerance far enough that she begins to question the child they created. After striking her cousin John and being sent to the red 
room (where her uncle died), Jane "resisted all the way: a new thing for me," resulting in being called a "mad cat" and threatened with restrains by the servants (Brontë 12-3). Jane's looming transformation from confused child to young woman is clear as her newfound, defensive will sparks imagery of madness and confinement. However, the Reeds's role in creating those traits and the present situation must also be considered. In the solitude of the red room, Jane understands that her treatment is "unjust" but does not understand why her efforts to "please" the family fail, even thinking that "All said I was wicked, and perhaps I might be so" (16-7). As a young child, she cannot be expected to understand her situation perfectly, so the fact that she is able to question who and what she is and how that relates to the treatment she receives is a major step towards freedom. She even understands that Mr. Reed's ghostly interference on her behalf would be "consolatory in theory" and "terrible if realised" (18). The fit that causes her to lose consciousness and ends her stay in the red room is a moment of transformation from attempted dutiful daughter to willful young woman (19). The time spent in the red room, however emotionally scarring, begins to break down Jane as she knows herself so far.

This process continues when she confronts Mrs. Reed for lying about her to Mr. Brocklehurst, the head of her new boarding school. Jane thinks, "Speak I must; I had been trodden on severely, and must turn: but how?" and proclaims that "I am not deceitful," exposing the core of her misery at Gateshead (Brontë 35). However cruel her aunt and cousins may be, their false proclamations of who and what she is make her realize she needs to be seen and heard in order to reclaim who she is. Mrs. Reed marks a change in Jane by speaking "in a tone in which a person might address an opponent of adult age" (35). Jane's success is profound, leading her to feel "my soul began to expand, to exult 
with the strangest sense of freedom, of triumph, I have ever felt" (35), though that feeling is soon replaced: "Something of vengeance I had tasted for the first time; as aromatic wine it seemed, on swallowing, warm and racy: its after-flavour metallic and corroding, gave me a sensation as if I had been poisoned" (36). Jane's quick change in emotions and turn to "vengeance" are reminiscent of Catherine and Heathcliff in Wuthering Heights, suggesting one possible (and ill-fated) path that Jane could have taken. By recognizing and then giving up anger, Jane avoids another confrontation with Mrs. Reed, but more importantly, she remains free, though not unchanged. When she attempts to read a book, "my own thoughts swam always between me and the page I had usually found fascinating"; during a walk outside, "the shrubbery was quite still: the black frost reigned ... I found no pleasure in the silent trees" (37). In these moments, Jane must set aside the minor pleasures of her past life and cross into (and through) the uncertainties of change.

Lowood is a kind of springtime for Jane; she is stripped down to a child but is nonetheless nurtured and allowed to grow. Even being chastised by Mr. Brocklehurst in front of the whole school proves a temporary set-back; he proclaims her "A careless girl!" and that "this girl is—a liar!" (Brontë 61, 63). Being spoken of as a child undermines the adulthood she achieved the day she confronted Mrs. Reed, and the vengeance she had cast off returns. Even so, as Alexandra Valint notes, Jane's goal isn't to be a perfect, angelic child (204). Even if she had "meant to be so good" while at Lowood, her real goal is to be "treated as an equal by those of my own age, and not molested by any," which she achieves through Helen Burns and Miss Temple (Brontë 64). From Helen, she learns that hard ship is easier to bear when she can rely on herself. When comparing their poor treatment from older women, Helen exclaims, "What a 
singularly deep impression her injustice seems to have made on your heart! No ill-usage so brands its record on my feelings" (55). Every correction Jane receives is a blow to her core, an insult or correction to the girl she wants to be; not so for Helen, who "[lives] in calm, looking to the end" (56). Religion dominates Helen's forward-looking perspective, and it is undoubtably influenced by her terminal illness as well. However, her critique of Jane's impressionability is well-founded, even if Jane will not fully realize it until she stands her ground by leaving Thornfield. From Miss Temple, she learns that both public and private identity negotiations are possible; by telling Miss Temple about her experiences at Gateshead, she succeeds in establishing herself as an honest child (66-7). Moreover, as "mother, governess, and, latterly, companion" to Jane, Miss Temple helps reinforce Jane's commitment to "duty and order" (78). Both Helen and Miss Temple emphasize steadiness over passions, and Jane becomes a diligent student and devoted teacher, a seemingly productive, happy conclusion of her youngest days. By the end of her time at Lowood, Jane's quiet demeanour is established yet still fragile. She explains that "my mind had put off all it had borrowed of Miss Temple ... I was left in my natural element, and beginning to feel the stirring of old emotions" (Brontë 78). The identity she was content with could not survive on its own. In many ways, it was not hers at all, but an extension of Miss Temple's. Regardless of the days and friendships she has enjoyed, Lowood cannot continue to support her:

I tired of the routine of eight years in one afternoon. I desired liberty; for liberty I gasped; for liberty I uttered a prayer; it seemed scattered on the wind then faintly blowing. I abandoned it and framed a humbler supplication; for change, stimulus: that petition, too, seemed swept off into vague space: 'Then," I cried, half 
desperate, "grant me at least a new servitude!" (79)

Jane's desire for "servitude" does not have to be a barrier to independence; it may be, as Nora Gilbert describes, "an important stepping stone on the pathway to the "New Woman' movement and beyond, blurring as it does the lines between work and domesticity, between isolation and privacy, between subjugation and liberation" (47980). However, Jane's decision is ultimately more personal: "such words as Liberty, Excitement, Enjoyment: delightful sound s truly; but no more than sounds for me; and so hollow and fleeting that it is mere waste of time to listen to them ... I have served here eight years; now all I want is to serve elsewhere. Can I not get so much of my own will? Is not the thing feasible? Yes" (Brontë 80). Just as she saw the drawbacks of vengeance, Jane sees the pitfalls of lofty dreams and a grandiose (to her) life. Continuing as a teacher, this time in a private house, is thus a logical step towards self-affirmation.

Unfortunately, almost immediately, Thornfield Hall fails to provide Jane with the "new servitude" she expected, instead thrusting her back into uncertainty. From the moment she reaches Thornfield, her assumptions are proven incorrect, and their replacements are little better: Mrs. Fairfax, the housekeeper, "treats me like a visitor ... I little expected such a reception; I anticipated only coldness and stiffness: this is not like what I have heard of the treatment of governesses; but I must not exult too soon" (Brontë 89). The warm reception is perceived positively, with its potentially temporary nature being the primary concern. Jane doesn't realize, though, that her status as "a visitor" leaves her caught between the roles of servant and socialite, a position that reignites her identity conflict; she cannot be the Jane she was when she left Lowood if she is to fit in at Thornfield. For his part, Rochester never adheres to Victorian expectations for 
governesses "to stay on the periphery" of the family (Gilbert 463). Instead, he insists on her company and that she "sit exactly where I placed [the chair] —if you please, that is" (Brontë 119); if guests are present, his "request" and "wish" for her presence is underpinned by his intent to "fetch her in case of contumacy" (153). What had been a welcomed reception as a visitor is now an uncomfortable kind of servitude, with Jane afforded the perks of a guest but not the freedom of leaving. Rochester's actions strip Jane of the governess role she thought she had, forcing her to reassess herself and him.

Disguised as a female fortune teller, Rochester continues to unsettle Jane's sense of self. Jane first states that she is not "cold," "sick," or "silly" (Brontë 177-8), but as he contests those claims, her defiance wanes, marking her tenuous grasp on how well she understands herself. The predicament does not go unnoticed, as he continues, "Your fortune is yet doubtful: when I examined your face, one trait contradicted another" (181). While likely saying this to encourage her to consider a future with him, he also touches on the core of her personal struggles: choosing when to discard and when to modify aspects of herself, especially those that are in conflict with each other, like "Jane Eyre" and "Jane Rochester" soon will be. He also sees the agency she has over her selfhood when he remarks, "It depends on yourself to stretch out your hand, and take it [happiness] up; but whether you will do so, is the problem I study" (181). Again, while the hope is that she will choose him, he foresees that Jane will ultimately be her own creator. This point is reinforced by her awareness of how Rochester's shifting personas affect her. In response to Rochester's questions of "What character did I act? My own?" she replies, "No: some unaccountable one. In short, I believe you have been trying to draw me outor in" (183). That is, of course, exactly what he is attempting to do: draw her out of her 
governess self and into Jane Rochester. Jane's main challenge now is not how to negotiate the servant and visitor roles but how to survive leaving both behind.

On the precipice of becoming a fiancée, Jane continues to see the flaws in her relationship with Rochester, but she stops short of acting on them. He continues to be assertive even in his marriage proposal, phrasing it as "I summon you as my wife" (Brontë 228). This wording recalls Jane's position as his servant and her former desire for "a new servitude" (79). Servitude in marriage is not what she sought, though, and she is quick to question his motivations, at first believing that "he mocked me" (228). She is not able to allay these feelings by looking at him, as he appears "agitated" with "strange gleams in the eyes," nor does she discover a concrete reason to trust him (229). Instead, she accepts his verbal commitment. Usually, a spoken declaration would be enough, but given her existing suspicions, it becomes an inadequate response, especially when Rochester proceeds to command her to "come to me-come to me entirely now" (229). Having been given the opportunity, he moves to possess Jane entirely, both in the sense of "owning" a wife and manipulating, or haunting, her mind. The critical issues with this marriage plan are shortly underscored when "the great horse-chestnut at the bottom of the orchard had been struck by lightning in the night, and half of it split away" (230). The split tree foreshadows their crumbling marriage and Jane's flight from Thornfield; she is the half of it "split away," and Rochester, still in Thornfield, is the unmoved portion. It also symbolizes Jane's identity split: the parts of her that are Jane Eyre are torn from the parts that will be Mrs. Rochester. They cannot be the same person in this marriage.

The flaws in their wedding plans continue to intensify; with their wedding looming, Jane rejects the constructed "Mrs. Rochester" identity and begins to assert the 
version of herself that will persist until the end of the novel. Once engaged, Rochester attempts to transform her into an aristocratic woman. Her reaction is telling: "Jewels for Jane Eyre sounds unnatural and strange: I would rather not have them," going so far as to say "you will not know me, sir" if he forces the matter (Brontë 232). The escalation from a preference to avoid jewellery to a declaration of being unrecognizable in them suggests that Jane is now fully aware of how others - and Rochester in particular-have constructed her past identities. Resisting material wealth is an imperative part of resisting an unwelcome transformation. This is not outright rebellion because she does not seek to destroy, only to maintain. Beyond controlling her physical appearance, one way to do so is to set aside her relationship with Rochester and "continue to act as Adèle's governess" and receive nothing but payment and his "regard" (242). When threatened, she retreats wholly from the new aspects of her identity (such as being a fiancé) and returns to the most recent, partially stable alternative, that of a servant. Jane formerly viewed marriage as a catastrophe, and she could not have been more correct (179). The kind of marriage proposed here would never be successful because it would be, variably, between one man and two women, the latter housed within one body.

Bertha understands this reality. Throughout Jane and Rochester's courtship, far from simply seeking revenge or being Jane's "double," Bertha is her contemporary as a woman. The basic parallels between Jane and Bertha are not difficult to find: both are women, live at Thornfield, and, at different times, marry Rochester. In one sense, as Jessica Campbell explains, "the frequently insisted-on affinity with Bertha thus emphasizes how vital it is for Jane to distinguish herself" (241). However, rather than needing to distinguish herself from Bertha to avoid becoming her, Jane needs to 
distinguish herself fully—-from Bertha, as well as from Rochester and her own younger self. By her own observations, Jane should have known that Grace Poole was not the source of the sounds because "Her appearance always acted as a damper to the curiosity raided by her oral oddities: hard-featured and staid, she had no point to which interest could catch" (Brontë 101). Grace's unremarkable appearance should be welcomed as a sign that she is doing well, and Jane's disappointment suggests that she remained willfully ignorant to Bertha's existence and what she represented: Rochester's shortcomings. "I believed that his moodiness, his harshness, and his former faults of morality ... had their source in some cruel cross of fate," she explains. "I thought there were excellent materials in him; though for the present they hung together somewhat spoiled and tangled" (134). More than guessing his tragic past, it is significant that she identifies the "materials in him" and their disarranged state. She knows he is not a stable man, and rather than fearing that, she seeks to support him. Bertha knows otherwise; immediately following Jane's reflections, Bertha burns Rochester's bed, and almost him (135-7). Although her actions could be read as revenge against an unfaithful husband, their proximity to Jane's sympathetic thoughts warn against Rochester's volatility. Until he is no longer "spoiled" or "tangled," the passion Jane feels will only burn her up. The hint isn't taken, though, and so Bertha must try again, this time on the eve of the wedding. Jane recalls that "she took my veil from its place; she held it up, gazed at it long, and then she threw it over her own head, and turned to the mirror. At that moment I saw the reflection of the visage and features quite distinctly in the dark oblong glass," features that were "fearful and ghastly to me" (254). By wearing the veil, Bertha attempts to make Jane reckon with her own reflection, to come to terms with what it means to be a 
bride of this Rochester. Whether he is made of "excellent materials" or not, the man he is now is not a suitable husband for either woman. Marrying him now would consign Jane to an identity—and body—-that she is neither familiar nor comfortable with.

The impact of this second attempt is most keenly felt when Jane repeats it on her own. She would have left for the wedding without looking in the mirror if Sophie, Adèle's nurse, had not implored her to look. As she looks, she also listens: "I saw a robed and veiled figure, so unlike my usual self that it seemed almost the image of a stranger. 'Jane!' called a voice, and I hastened down” (Brontë 257). Brides do look different on their weddings days, and the issue in Jane's case is that the lack of recognition is paired with a verbal reminder of who she is. The call likely came from Rochester, but attributing it to "a voice" means it could be her own subconscious, especially considering this is not her last encounter with ethereal voices. The reminder's relevance is seen moments later when "I was hurried along by a stride I could hardly follow ... I wonder what other bridegroom ever looked as he did — so bent up to a purpose, so grimly resolute" (258). Just as she lost herself in the mirror, she is losing Rochester. Physically, she is outpaced by him, and emotionally, she cannot sympathize with him, nor he with her. Becoming Mrs. Rochester now would set her on a path of desire turned banishment.

By resolving to leave Rochester, Jane asserts her own identity more fully than at any previous point in her life. When questioning what her next step would be, she speaks out loud to herself, asking first "what am I to do?" and then "Let me be torn away, then! . .. Let another help me!" Or, more accurately, she speaks to her selves, who answer silently: "the answer my mind gave_-'Leave Thornfield at once'—was so prompt, so dread, that I stopped my ears"; "But, then, a voice within me averred that I could do it; 
and foretold that I should do it"; "No; you shall tear yourself away, none shall help you: you shall, yourself, pluck out your right eye: yourself cut off your right hand: your heart shall be the victim; and you, the priest, to transfix it" (Brontë 267). Jane's descriptions of a voice from her "mind" and "a voice within me" suggest that she is hearing at least two distinct voices. They agree and urge her external voice and body to follow, fortified with the resolve to remain "Jane Eyre," not "Jane, mistress of Rochester." Her resolve withstands Rochester's pleas for her to stay, and she determines that, "if I were so far to forget myself and all the teaching that had ever been instilled into me," he would cast her off like his previous mistresses (279). Explicitly, she is referring to her social, artistic, and intellectual accomplishments. Implicitly, the "myself" and "teaching" she references are those that Rochester has cultivated; being herself with him is not an option, and she refuses that fate. Likewise, she rejects his claim that she has ruined his life: "I no more assign this fate to you than I grasp at it for myself. We were born to strive and endureyou as well as I: do so" (283). In this moment, Jane firmly impresses the futility of looking at him as a product of her actions, or she of his. Thus she departs firmly, and only, as Jane Eyre, even as her love for Rochester still lives.

Shortly after leaving, she leaves her parcel in the coach, making her "absolutely destitute" (Brontë 288). Stricken of material possessions, her goals are clear: "Life, however, was yet in my possession; with all its requirements, and pains, and responsibilities. The burden must be carried; the want provided for; the suffering endured; the responsibility fulfilled" (291). From this moment on, every aspect of her being - from physical needs to internal ethics — is tested. She resists begging for as long as possible and seeks employment or humble barters instead, excusing those who decline 
(294). Moreover, when she feels death is near, she chooses the woods over the town for it is "far better that the crows and ravens . . . should pick my flesh from my bones, than that they should be prisoned in a workhouse coffin and moulder in a pauper's grave" (295). This choice grants her freedom from the possibility of becoming a "Jane Doe" in a town ledger. Travelling as she did through fatigue and fear and arriving at the Rivers's unchanged is a testament to her dedication to her selfhood. She was miserable, yet she held to the conviction she relayed to Rochester before departing: "Laws and principles are not for the times when there is no temptation: they are for such moments as this, when body and soul rise in mutiny against their rigour, stringent are they inviolate they shall be" (284). At that time, she was speaking of her love for Rochester pitted against her religious and legal morals. Now, near death, the ideas apply to her continued empathy for others and desire for independent income, or when that is not possible, for the meagerest of charities. She experiences no temptation to steal or trespass, and in such a way, her physical ordeal may be a painful memory, but it does not haunt her conscience.

As a result, Jane's relationship with Mary and Diana can flourish, and through it, "Jane Elliot" becomes a foggy reflection of her real self. Some of her traits are consistent with her past life, such as how, regarding Diana, "it was my nature to feel pleasure in yielding to an authority supported like hers: and to bend, where my conscience and selfrespect permitted, to an active will” (Brontë 307). She acted this way with Rochester, obeying his commands until doing so would render her his mistress. Likewise, when she is well enough, she follows Mary and Diana's scholastic pursuits: "They were both more accomplished and better read than I was: but with eagerness I followed the path of knowledge they had trodden before me" (313). This "eagerness" reflects her tendency to 
be a follower just as much as calls back to her successful studies at Lowood. And yet, there are signs that she cannot settle into this identity. Early on, she "gave an involuntary half-start at hearing the alias; I had forgotten my new name" (311). Indeed, this seems to be her general state of mind, having absently written "Jane Eyre" on a scrap piece of paper, thus revealing herself to St. John (340). As soon as her identity as Jane Eyre is revealed to all, her former dominance resurfaces as she demands that she and her cousins take equal shares of her new twenty-thousand-pound inheritance (347). The submissive elements of the younger Jane Eyre and the fleeting Jane Elliot remain in contest with her strong will, though the fact that such conflict does not damage her relationship with Mary and Diane also suggests a certain stability in her relationships with other women.

Her relationship with St. John is much more tumultuous; what begins as a "yielding" similar to Diane turns into a resolute refusal. Jane's decision to abandon learning German in favour of Hindostanee, at St. John's request, is not wholly her own: "St. John was not a man to be lightly refused: you felt that every impression made on him, either for pain or pleasure, was deep-graved and permanent. I consented" (Brontë 335). His authority is absolute, and her position as a guest in his house gives her few options. Once more, like at Gateshead and Thornfield, she is neither servant nor family, and in this instance, her situation mirrors the former more than the latter. She goes on to explain that "I did not love my servitude: I wished, many a time, he had continued to neglect me" (355). Her dislike and distrust of St. John's attention continues, with it described as "an awful charm" and an "iron shroud" $(358,360)$. She resolutely refuses to become his missionary wife because it would destroy her selfhood completely: "I will give the missionary my energies — it is all he wants— but not myself: that would be only 
adding the husk and shell to the kernel. For them he has no use: I retain them" (362). Travelling as his sister instead remains an option because she "should still have my unblighted self to tun to ... There would be recesses in my mind which would be only mine, to which he never came; and sentiments grown there fresh and sheltered, which his austerity could never blight, nor his measured warrior-march trample down”(363). But even this hold over her is shattered when she "heard a voice somewhere cry-'Jane! Jane! Jane!"” (374). Later on, Rochester admits to calling for her, and it may be assumed that, through some supernatural amplification, she was able to hear him (398). Given Jane's previous experiences with opportune voices, though, it is equally possible that the voice was from inside her, emulating what she remembered Rochester's voice to sound like in order to bring her out of St. John's captivating speech. Through St. John, the identity of Jane Eyre — and the potential to become Jane Rochester —is threatened, yet it emerges stronger for having faced its own conflicting desires of servitude and freedom.

However, she must still decide what she is willing to lose by joining Rochester. When she departs for Thornfield, she believes Bertha is still alive, and she questions what she will do if she finds him still there and still married: "Could I but see him! — but a moment! Surely, in that case, I should not be so mad as to run to him? I cannot tell-I am not certain. And if I did-what then?" (Brontë 376-7). Like the temptation to marry St. John despite her better judgement, this temptation to be with Rochester threatens her dedication to her decisions and values. Even while absent—or because of it—Rochester's ability to "draw [her] out—or in" (183) grows. She is spared from facing this issue headon because Bertha is already dead, and while that makes it easier for return to Rochester, it also means she did not work through her conflicting emotions. Her fears of becoming a 
mistress dissipate, but the possibility that she would have given into them remains. With this issue left unresolved, the reader is left in a kind of limbo as well; far from finding a personal guide, they are faced with the murky waters of uncertainty. And yet, this uncertainty also works to prevent the novel from becoming the same type of problematic influence as Rochester or St. John themselves. Because there is no singular path to follow, readers are encouraged to deliberate this juncture by themselves.

There is also the issue of Ferndean Manor itself, which Rochester admits is in such a poor state that it would have been cruel to send Bertha there: "Probably those damp walls would soon have eased me of her charge" (Brontë 269). If the house is a death-sentence for the first Mrs. Rochester, what is it for the second? The route to Ferndean is no more reassuring, covered in "darkness of natural as well as of sylvan dusk" so dense with foliage that she thought she "lost my way" and must exit through "a portal" (383). In lieu of a direct confrontation of desires and values, passing through the forest is a symbolic representation of what she leaves behind, including the ready companionship of Mary and Diana. She also loses the right to privacy, especially of her own mind, which was one of the values she clung to when deciding not to marry St. John. She describes being so close to Rochester as to be almost the same person (401), so it seems unlikely that there are as many (or any) "recesses in my mind that would be only mine" (363). Sacrificing this inner solitude is problematic, not just because it suggests a willingness to let Rochester fully occupy her thoughts. Most of her major life decisions have been made alone, including leaving both Lowood and Thornfield. If she is never truly alone again, her mobility is limited.

Once at Ferndean Manor, and shortly thereafter married to Rochester, she defines 
herself as a hybrid of Jane Eyre and Jane Rochester. She maintains the somewhat "yielding" demeanour and adds to it a gentle firmness (rather than the sharp will of her youth) that sets boundaries without destroying the relationship they surround. In response to Rochester's objections that she will be unhappy with him, Jane demonstrates that she is not looking, solely, for "sovereignty through service" (Marcus 213). She explains that "I love you better now, when I can really be useful to you, than I did in your state of proud independence, when you disdained every part but that of the giver and protector" (Brontë 396). In almost the same breath, Jane expresses a desire for another "new servitude" and a vexation at being manipulated. Despite her earlier devotion to Rochester, disagreements like those around the jewellery were a dividing factor between the couple. Combining her desire to help him and the sharp memory of their conflicts introduces Rochester to the new Jane Eyre, one that is less likely to permit his extreme emotions and actions, even if they have waned in his new state. In this way, Jane merges the Jane of her unmarried youth and the older, wiser woman that took her place.

Jane and Rochester also share "physical" wounds that serve as reminders of their past lives without holding back their future. James Phillips argues that conversation holds their marriage together and that it works "because they want to exist in a conversation with each other, not because they understand each other" (213). The implication is that the relationship will take a kind of work quite different from servitude. However, Jane and Rochester share an equally hurtful experience that facilitates their understanding of each other, much in the same way that the creature wants a bride that would "have the same defects" as him (Shelley 110). During the tortuous decision to leave Thornfield, Jane (metaphorically) stabs out her right eye and cuts off her right hand (Brontë 267); in 
the Thornfield fire, Rochester loses his right hand and left eye, as well as sight in his right eye (382). When she reaches Ferndean Manor, she becomes "his vision" and his "right hand," though he eventually regains some sight (401). Even though their external physical health is different, both have suffered in the same way, and their shared pain brings them closer together. Jane is given the unconditional love she has sought all her life, and it heals her invisible wounds. Rochester gains an extension of himself, one who implicitly understands how to "[gaze] on his behalf" and "[put] into words the effect of . . . the landscape before us; the weather around us" (401). They need each other to be whole, yet they still exist apart. They rely one each other without wavering into the more dangerous ground of shared souls like Catherine and Heathcliff do.

Jane Eyre does not offer a woman that is wholly removed from patriarchal elements of society; it still ends in a marriage that is, while rather solitary, not overtly different than other marriages. The novel's critical contributions to discourses about female identity are not that established social, secular, and spiritual structures need to be torn down or submitted to. Instead, its contributions are in the holistic depiction of Jane's life, which goes beyond the creature's and Catherine's tragically short lives and Cathy's happy, if abbreviated, ending. Jane Eyre charts Jane's journey through troubled, manipulated childhood and impressionable adolescence and marks, each time, the consequences of becoming what others want. Equally so, it emphasizes the benefits (if also hardships) of seeking and affirming an identity that provides personal stability and happiness before all else. Claiming that Jane was "just" Jane at the novel's end with no trace of Rochester's influence misses the point. She will always be influenced by him because she loves him, but that love does not rule or threaten her anymore. 


\section{CONCLUSION}

When put in conversation with each other, Frankenstein, Wuthering Heights, and Jane Eyre become a nuanced public discourse of what it means to be a woman in Victorian England; although the novels include familiar models of domesticity, they go beyond the public and private surface to portray women's personal, internal lives. They become a view of women as they understand (or do not understand) themselves to be. In equal measure, they mark how social expectations and familial pressures influence women and how women respond to those influences. Through characters like the creature, his bride, and Catherine, the novels outline the problems of identities built primarily on the demands and preferences of others. These characters are followed by Cathy and Jane, characters that successfully build their identities by moderating outside influences in relation to their personal values and desires. The progression from widespread death and loss to life and marriage suggests that female gothic novels advocated for women's abilities to control their own lives. Following the lives of each feminine character makes it apparent that knowledge and action are critical. Characters must first determine how the people around them amplify or weaken particular traits, like dominance or devotion. If this step is prevented (like with the bride) or interrupted (like with the creature), the potential for death or other hardships increases. If it is completed, then the characters can then asses the desirability of the new traits and how they interact with their existing self image and accept, discard, or modify them accordingly. This process gives female characters control over their inner selves and, to a degree, those 
who would seek to change them. By coding this process throughout a genre, female gothic novels foreground women as people with agency rather than passive products of their surroundings.

This analysis of women's lives builds on decades of feminist criticism that initially drew attention to female agency and desire in female gothic novels. Carolyn Heilbrun and Catharine Stimpson tasked scholars with finding and stopping problematic gendered cycles in literature, and doing so remains an ongoing effort. As part of that effort, analyzing Victorian identity conversations continues to foster a culture of understanding through and about older texts. As classic, canonical novels, Frankenstein, Wuthering Heights, and Jane Eyre are studied and restudied, with the shape of that scholarship changing with time. With this in mind, this thesis emphasizes both social changes and human continuity. Mary Shelly, Emily Brontë, and Charlotte Brontë faced different social barriers than many modern women, yet their system for working through these barriers persists to this day and partially accounts for why their novels are still beloved today. The tension between what the novels represent—especially a complacency with colonial ideals—and what underpins them—feminine identity—makes approaching them from a single angle ineffective. This thesis, then, offers an interdisciplinary way of thinking about female writers, characters, and readers that exists in tandem with the other forces at play in the novels.

One such force is the network of social systems in Victorian England. Patriarchy is the most explicit system that female gothic novels critique, and other, smaller systems operate within it. For instance, Sharon Marcus argues for the elasticity of female friendships. Close female friendships are a rarity in Frankenstein and Wuthering Heights, 
and even in Jane Eyre they are not persistent. The original application of the elastic system to female friendship, then, doesn't quite capture what is happening within these novels, but expanding it to personal growth more broadly does. In Frankenstein, the creature undergoes recognizably feminine domestic training and education despite being male, and in contrast, both Catherine and Cathy in Wuthering Heights displays masculine dominance over other characters. Jane Eyre offers the closest parallel to Marcus's original system through Jane's relationship with Helen and Miss Temple, and she undergoes the most prolonged process of self exploration and development. Identity formation, then, isn't a linear track of either accepting or rejecting influences and remaining the product of those choices. Instead, it is a recursive process that continually re-establishes and tests its own boundaries, and viewing it as one system among many provides a method for close analysis without becoming disconnected from its surrounding contexts.

The elastic system should not be confined to the texts themselves, either. Victorian notions of identity could only "bend" so much before they needed to be recognized as irrecoverably changed. The elastic system provided female writers with a way of coding ideas into texts that could and would be read, but they started a conversation that was not meant to end. Instead, there are numerous pockets of elastic systems throughout female gothic novels and around the generations of women that follow. Utilizing them makes the texts' ideas familiar and feasible for their first audiences and recognizable to later ones. However, there is no such elasticity surrounding these groups of systems; there is always forward momentum, a steady drive toward s change. Even if modern readers and scholars quibble with elements of the novels, especially their 
marriage-based endings, the female characters and their lives to that point continue to resonate. Dissatisfaction with the endings but not the core narrative is a sign that the primary work of these novels is to support real women as they decide for themselves who they are and what they want to do; it is not the novels' role to determine their final selves. Instead, the female gothic as a genre is "timeless" because it exists without an end. There is no neat conclusion to its ideas because the voices of its women-past, present, and future-determine that on their own.

This lack of an ending also furthers the idea that there is no single, comfortable solution for the challenges that female gothic novels explore, making it unfair to judge female gothic writers as either being "successful" or "unsuccessful" in providing them. Likewise, the "angel" and "madwoman" binaries, prevalent as they are in the texts and older criticism, serve as artificial extremes. Therefore, this thesis suggests adapting Sarah Ahmed's idea of "moving on" as a more flexible lens for understanding complex female characters. "Moving on" implies that characters' past traumas or barriers do not need to be completely resolved in order for them to have a positive future. Frankenstein fits this idea to a degree because the creature accepts Victor's death, and thus his own, as a natural progression. Nothing was "fixed" for the creature, yet his death is not framed as his failure or Victor's triumph. Catherine's death parallels the creature's; she is reunited with Heathcliff, but their presumed presence as ghosts suggest that the past remains alive as well. Cathy, too, remembers her past even as she builds a new future on the same grounds. Jane must also part with her family and enter Rochester's secluded world; even though she leaves part of her life behind, her position as an older narrator confirms the long-term stability and happiness she found by making choices that considered her past 
experiences. None of these characters have an idyllic ending wholly removed from earlier challenges, yet each offers a different kind of "closure" by emphasizing that, whether in life or death, there are ways to move on.

Female gothic novels continue to offer rich potential for future study. Within the Victorian period itself, additional novels can be added to Frankenstein, Wuthering Heights, and Jane Eyre to expand the record of conversations between women. More recent texts, such as Alice Munro's "Runaway," are an opportunity to see how the conversation as developed decades later yet within the same genre. Each new novel creates the opportunity to explore how existing processes, including identity formation, are impacted by individual women's circumstances. This is an especially important step as Victorian studies more broadly works to confront racism within the texts it studies and in their real-world manifestations. Seeing both what has and has not changed for individual people makes it possible to connect with and address the past while also supporting positive futures. Thus, the intent is not to end with the ideas presented here, in the same way that the conversations in these novels are not over. Instead, moving forward, the ideas should become part of continued efforts to build on past contributions and generates new modes of thinking. 


\section{REFERENCES}

Ahmed, Sara. "The Contingency of Pain.” The Cultural Politics of Emotion. Edinburgh University Press, 2014. JSTOR, https://www.jstor.org/stable/10.3366/j.ctt1g09x4q.6.

Armitt, Lucie. "The Gothic Girl." Women and the Gothic: An Edinburgh Companion, edited by Avril Horner and Sue Zlosnik, Edinburgh UP, 2016, pp. 60-73. JSTOR, http://www.jstor.com/stable/10.3366/j.ctt1bgzdfx.8.

"Art XII. Frankenstein; or the Modern Prometheus." The British Critic, vol. 9, Apr. 1818, pp. 432-8. Hathitrust, https://hdl.handle.net/2027/inu.30000080765005.

Benford, Criscillia. "'Listen to My Tale': Multilevel Structure, Narrative Sense Making, and the Inassimilable in Mary Shelley's 'Frankenstein'." Narrative, vol. 18, no. 3, 2010, pp. 324-346. JSTOR, http://www.jstor.com/stable/40856416.

Brontë, Charlotte. Jane Eyre: An Authoritative Text, Contexts, Criticism, $4^{\text {th }}$ ed., edited by Deborah Lutz, W. W. Norton \& Company, 2016.

Brontë, Emily. Wuthering Heights. Dover, 1996.

Brown, Marshall. "Frankenstein: A Child's Tale.” NOVEL: A forum on Fiction, vol. 36, no. 2, 2003, pp. 145-175. JSTOR, https://www.jstor.org/stable/1346124.

Butler, Judith. Afterword. A Life with Mary Shelley, by Barbara Johnson, Stanford UP, 2014, pp. 37-50.

Campbell, Jessica. "Bluebeard and the Beast: The Mysterious Realism of Jane Eyre." Marvels \& Tales, vol. 30, no. 2, 2016, pp. 234-250. JSTOR, https://www.jstor.org/stable/10.13110/marvelstales.30.2.0234.

Crain, Patricia. Reading Children: Literacy, Property, and the Dilemmas of Childhood in 
Nineteenth-Century America. U of Pennsylvania P, 2016.

Geerken, Ingrid. “'The Dead Are Not Annihilated': Mortal Regret in 'Wuthering Heights." Journal of Narrative Theory, vol. 34, no. 3, 2004, pp. 373-406. JSTOR, http://www.jstor.com/stable/30224613.

Gilbert, Nora. “A Servitude of One's Own: Isolation, Authorship, and the NineteenthCentury British Governess.” Nineteenth-Century Literature, vol. 69, no. 4, 2015, pp. 455-480. JSTOR, https://www.jstor.org/stable/10.1525/ncl.2015.69.4.455.

Gilbert, Sandra M. and Susan Gubar. The Madwoman in the Attic: The Woman Writer and the Nineteenth-Century Literary Imagination. 1984. Veritas, 2020.

Halberstam, Judith [Jack]. Skin Shows: Gothic Horror and the Technology of Monsters. Duke UP, 1995.

Hawley, Erin. “The Bride and Her Afterlife: Female Frankenstein Monsters on page and Screen.” Literature/Film Quarterly, vol. 43, no. 3, 2015, pp. 218-231. JSTOR, https://www.jstor.org/stable/43799028.

Heiland, Donna. Gothic \& Gender: An Introduction. Blackwell Publishing, 2005.

Heilbrun, Carolyn and Catharine Stimpson. "Theories of Feminist Criticism: A Dialogue." Feminist Literary Criticism: Explorations in Theory, edited by Josephine Donovan, 2nd edition, University Press of Kentucky, 1989, pp. 61-73. Hoeveler, Diane Long. Gothic Feminism: The Professionalization of Gender from Charlotte Smith to the Brontës. Pennsylvania State UP, 1998.

“Jane Eyre: An Autobiography." The Era, 1847, p. 9. 1838-1939 LON LD73 NPL. The British Newspaper Archive, the British Library, London.

Jourdrey, Thomas J. "Well, we must be for ourselves in the long run": Selfishness and 
Sociality in Wuthering Heights." Nineteenth-Century Literature, vol. 70, no. 2, 2015, pp. 165-193. JSTOR, https://www.jstor.org/stable/10.1525/ncl.2015.70.2.165.

Jung, Daun. “'Currer Bell': Jane Eyre’s Alternative Proper Name. Brontë Studies, vol. 46, no. 1, 2021, pp. 43-55. Taylor and Francis, https://doi.org/10.1080/14748932.2021.1835064.

"Literary Intelligence. Review of New Publications. Frankenstein; or, the Modern Prometheus." La Belle Assemblée; or, Bell's Court and Fashionable Magazine, vol. 17, Mar. 1818, pp. 139-141. Hathitrust, https://hdl.handle.net/2027/nyp.33433081673406.

Lukits, Steve. “The Devastated Nest: Crises of Identity in 'Wuthering Heights' and 'Antigone.'” Antigone, special issue of An Interdisciplinary Critical Journal, vo. 41, no. 3, 2008, pp. 103-116. JSTOR, https://www.jstor.org/stable/44029642.

Marcus, Sharon. "The Profession of the Author: Abstraction, Advertising, and Jane Eyre. PMLA, vol. 110, no. 2, 1995, pp. 206-219. JSTOR, https://www.jstor.org/stable/462911.

Markotic, Lorraine. "Desire, Identification, and Two Peculiar Deaths: The Long Story of Wuthering Heights.” Mosaic: An Interdisciplinary Critical Journal, vol. 52, no. 2, 2019, pp. 75-91. ProjectMUSE, https://muse.jhu.edu/article/729770.

Muller, Alexandra. "Charlotte Brontë: Insurrection and Resurrection.” The Hudson Review, vol. 69, no. 3, 2016, pp. 433-443. JSTOR, https://www.jstor.org/stable/44788479.

Mussell, Kay J. “'But Why Do They Read Those Things?': The Female Audience and the 
Gothic Novel." The Female Gothic, edited by Juliann E. Fleenor, Eden Press, $1893,57-68$.

New man, Beth. "Narratives of Seduction and the Seductions of Narrative: The Frame Structure of Frankenstein." ELH, vol. 53, no. 1, 1986, pp. 141-163. JSTOR, http://www.jstor.com/stable/2873151.

Phillips, James. "Marriage in Jane Eyre: from Contract to Conversation. Brontë Studies, vol. 33, no. 3, 2009, pp. 203-217. Taylor and Francis, https://doi.org/10.1179/174582208X338559.

Pike, Judith E. 'My name was Isabella Linton': Coverture, Domestic Violence, and Mrs. Heathcliff's Narrative in Wuthering Heights." Nineteenth-Century Literature, vol. 64, no. 3, 2009, pp. 347-383. JSTOR, https://www.jstor.org/stable/10.1525/ncl.2009.64.3.347.

Rich, Adrienne. "Jane Eyre : The Temptations of a Motherless Woman." Critical Essays on Charlotte Brontë, edited by Barbara Timm Hall, 1990, pp. 142-55.

Rigby, Elizabeth. "Vanity Fair—and Jane Eyre.” Quarterly Review, 1849. P.P.6256.d. The British Library, London.

Salotto, Eleanor. “'Frankenstein' and Dis(re)membered Id entity.” The Journal of Narrative Technique, vol. 24, no. 3, 1994, pp. 190-11. JSTOR, https://www.jstor.org/stable/30225415.

Schaffer, Talia, Romance's Rival: Familiar Marriage in Victorian Fiction. Oxford UP, 2016.

Schoene-Harwood, Berthold. Mary Shelley: Frankenstein. Columbia UP, 2000.

Scott, Walter. "Remarks on Frankenstein, the Modern Prometheus; a Novel." 
Blackwood's Edinburgh Magazine, vol. 2, no. 12, Mar. 1818, pp. 613-20 .

Hathitrusti, https://hdl.handle.net/2027/mdp.39015030603982.

Shelley, Mary Wollstonecraft. Frankenstein, $2^{\text {nd }}$ edition, edited by Susan J. Wolfson. Pearson Education, 2007.

Showalter, Elaine. "Literary Criticism: Review Essay.” Signs, vol. 1, no. 2, 1975, pp. 435-460. JSTOR, http://www.jstor.com/stable/3173056.

Spacks, Patricia Meyer. The Female Imagination. Alfred A. Knopf, Inc., 1975.

Steinitz, Rebecca. "Diaries and Displacement in "Wuthering Heights." Studies in the Novel, vol. 32, no. 4, 2000, pp. 407-419. JSTOR, http://www.jstor.com/stable/29533412.

Valint, Alexandra. “Accepting Adèle in Charlotte Brontë's Jane Eyre.” Dickens Studies Annual, vol. 47, 2016, pp. 201-222. JSTOR, https://www.jstor.org/stable/10.5325/dickstudannu.47.2016.0201.

“Valperga.” Blackwood's Edinburgh Magazine, vol. 13, Mar. 1823, pp. 283-93.

Hathitrust, https://hdl.handle.net/2027/mdp.39015030603875.

Wilks, Brian. “Jane Eyre Revisited.” Brontë Studies, vol. 41, no. 4, 2016. Taylor and Francis, https://doi.org/10.1080/14748932.2016.1222705.

Wilson, Cheryl A. "Female Reading Communities in Jane Eyre." Brontë Studies, vol. 30, no. 2, 2005, pp. 131-139. Taylor and Francis, https://doi.org/10.1179/147489305x45145. 


\section{CURRICULUM VITA}

Hayley Salo

\section{EDUCATION}

M.A. in English, May 2021

University of Louisville, Louisville, KY

B.A. in English, Humanities minor, 2014

Simon Fraser University, Burnaby, BC, Canada

\section{AREAS OF SPECIALIZATION}

Victorian and post-colonial literature; gender and sexuality studies; writing center studies

\section{TEACHING AND TUTORING EXPERIENCE}

\section{University of Louisville, Louisville, KY}

Composition Instructor, August 2020-May 2021

Designed online, asynchronous sections of first-year composition courses that are ad aptable to students' individual needs. Facilitate student und erstanding of rhetoric, audience, and academic writing genres. Encourage community learning and collaborative writing through group discussions and peer reviews. Reinforce effective writing and identify growth potential through written feedback and conferences.

Morton Endowed Chair's Research Assistant, August 2020-May 2021 Research written and physical aspects of Victorian life and culture. Create literature reviews, including article summaries and gap identification. Locate primary sources in local and international archives. Assist with copy editing.

University Writing Center Consultant, August 2019-June 2020 Provided in-person and online writing feedback. Worked with high school dual credit, und ergraduate, and graduate writers from all disciplines. Engaged writers in brainstorming, drafting, and revising. Shared rhetorical and genre-specific knowledge. Conducted in-class presentations about the Writing Center and research strategies. Learned and implemented current composition pedagogy. 
Huntington Learning Center, Bellevue, WA

Exam Prep and Writing Tutor, January 2018-June 2019

Applied Huntington's reading and writing tutoring strategies for stand ardized tests. Adapted strategies for students with different learning preferences. Remained up-to-date with high school and post-secondary program requirements.

The Princeton Review, New York, NY

Online Writing Tutor, June 2015-June 2016; January 2018-July 2019 Provided feedback on high school and post-secondary writing in synchronous and asynchronous online settings. Used reader's response and revision-focused ped agogy to as sist writers across the country. Taught MLA, APA, and Chicago style citation rules.

Private Tutor, Coquitlam, BC, Canada

In-person Reading and Writing Tutor, January 2014-June 2014

Designed lesson plans, reading and writing assignments, and conversation practice for young multilingual writers. Created academic reading and writing strategies for university students; guided them through university expectations.

Douglas College, New Westminster, BC

Online Peer Tutor, May 2010-December 2013

Tutored writing with first - and second-year college students in an asynchronous environment. Mentored new tutors in best-practices and troubleshooting strategies. Participated in the development and launch of Write Away, the region's multi-university eTutoring platform.

\section{COMMUNITY INVOVLEMENT}

English Department Representative, Graduate Student Council, August 2020 present

M.A. Liaison, English Graduate Organization, August 2020-present

\section{CONFERENCES AND PROFESSIONAL DEVELOPMENT}

Conference on College Composition and Communication, panelist, April 2021

Louisville Conference on Literature and Culture Since 1900, panel chair,

University of Louisville, Louisville, KY, February 22, 2020

College Reading and Learning Association(CRLA) certified master tutor, 2011

\section{CURRENT PROJECTS}

Salo, Hayley. "Structures of Pain and Pleasure: Colonial Forces in Joshua Whitehead's Jonny Appleseed," submitted to Studies in American Indian Literatures 


\section{SCHOLARSHIPS AND AWARDS}

Princeton Review Essay Writing Tutor of the Month, \$50 (2018)

Ken McGlinchey English Scholarship, \$1,188 (2011)

Douglas College President's Entrance Scholarship, \$10,000 (2009)

Yves Duamel Memorial Bursary, \$500 (2009)

Maple Ridge Secondary School Music Scholarship, \$500 (2009) 